\title{
Morphology, ultrastructure, and molecular phylogeny of the ciliate Sonderia vorax with insights into the systematics of order Plagiopylida
}

Letizia Modeo $^{{ }^{*}}$, Sergei I Fokin ${ }^{1,2}$, Vittorio Boscaro ${ }^{1}$, Ilaria Andreoli ${ }^{1}$, Filippo Ferrantini ${ }^{1}$, Giovanna Rosati ${ }^{1}$, Franco Verni ${ }^{1}$ and Giulio Petroni ${ }^{1}$

\begin{abstract}
Background: Ciliates of the family Sonderiidae are common members of the eukaryotic communities in various anoxic environments. They host both ecto- and endosymbiotic prokaryotes (the latter associated with hydrogenosomes) and possess peculiar morpho-ultrastructural features, whose functions and homologies are not known. Their phylogenetic relationships with other ciliates are not completely resolved and the available literature, especially concerning electron microscopy and molecular studies, is quite scarce.
\end{abstract}

Results: Sonderia vorax Kahl, 1928 is redescribed from an oxygen-deficient, brackish-water pond along the Ligurian Sea coastlines of Italy. Data on morphology, morphometry, and ultrastructure are reported. S. vorax is ovoid-ellipsoid in shape, dorsoventrally flattened, $130 \times 69 \mu \mathrm{m}$ (mean in vivo); it shows an almost spherical macronucleus, and one relatively large micronucleus. The ventral kinetom has a "secant system" including fronto-ventral and fronto-lateral kineties. A distinctive layer of bacteria laying between kineties covers the ciliate surface. Two types of extrusomes and hydrogenosomes-endosymbiotic bacteria assemblages are present in the cytoplasm. The phylogeny based on $18 \mathrm{~S}$ rRNA gene sequences places S. vorax among Plagiopylida; Sonderiidae clusters with Plagiopylidae, although lower-level relationships remain uncertain. The studied population is fixed as neotype and the ciliate is established as type species of the genus, currently lacking.

Conclusions: This is the first description of a representative of Sonderiidae performed with both morphological and molecular data. To sum up, many previous hypotheses on this interesting, poorly known taxon are confirmed but confusion and contradictory data are as well highlighted.

Keywords: Ectosymbionts, FISH, Hydrogenosomes-endosymbionts assemblages, Oxygen deficient environment, Plagiopylida, Phylogeny, Silver-nitrate staining, SSU rRNA, Sulphide fauna, Ultrastructure

\section{Background}

The genus Sonderia was established by Kahl in 1928 [1] for ciliates collected from Oldesloe salt marshes (Hamburg region, Germany) and later on from the Island of Sylt (North Sea, Germany). These interesting ciliates are ubiquitous and common in the sapropelic environment of salt marshes and in ecologically similar brackish water sites with oxygen deficiency [2-9].

\footnotetext{
* Correspondence: Imodeo@biologia.unipi.it

'Unit of Protistology-Zoology, Department of Biology, University of Pisa, via A. Volta 4/6, Pisa 56126, Italy

Full list of author information is available at the end of the article
}

Within the genus Sonderia quite conspicuous, ovoidellipsoid ciliates are included. These are dorsoventrally flattened, uniformly ciliated, and show a conical, subapical oral cavity. The cell length of genus representatives varies, according to the species, from 80 to $250 \mu \mathrm{m}$. Their surface is covered by a distinctive layer of bacteria organized in parallel along the host body axis and plunged in a gelatinous coating between kineties. From a few to numerous long, needle-shaped extrusomes are present in the cortex. Oral kineties extend from somatic ones, both organized as monokinetids, and run perpendicularly to the upper and lower lips of the oral cavity opening. A transversely

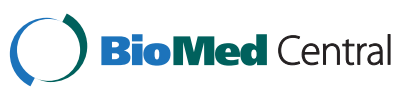


striated band arises near the right margin of the oral cleft and dorsolaterally runs down [10-13].

After Kahl, 1928 [1] the genus Sonderia was splitted into four related genera - Sonderia, Parasonderia, Kahlisonderia, and Oncosonderia [14-16]. All these genera share some morphological features such as: general shape, subapical position of oral cavity, transversely striated band passing from the oral cleft, and a surface gelatinous layer with embedded bacteria. However, silver impregnation and/or different staining methods were never applied to describe the majority of the species and the type species of Sonderia was never established [15,17]. As a curiosity, six out of eight species described during the genus establishment were marked in the key publication [11] as "Kahl, 1930", but no articles dealing with Sonderia published in 1930 are in fact available $[15,18]$.

Molecular studies on Sonderia lack at present, while there is a single study on a representative of the family Sonderiidae, Parasonderia vestita [16]. Only a few $18 \mathrm{~S}$ rRNA gene sequences are available for other taxa belonging to the class Plagiopylea, namely the plagiopylids Plagiopyla [19,20], Lechriopyla [21] and Trimyema [19,22-24], and the odontostomatid Epalxella [25]. The fact that these sequences form a clade is the main uniting feature of the class itself [12]. Members of the class Prostomatea usually appear to be the most closely related to Plagiopylea in phylogenetic analyses.

In the present paper Sonderia vorax Kahl, 1928 is redescribed as type species of the genus and neotypified using a modern multidisciplinary analytical approach which combines morphological (i.e. live, stained, scanning, and transmission electron microscopy) with morphometric and molecular analysis.

\section{Methods}

\section{General remarks}

The neotype population of Sonderia vorax was discovered in three brackish water samples with a 4-8\% salinity range; together with oxygen level (see below), salinity was measured using an OX 22 oxygen meter (Aqualytic, Langen, Germany). All the samples came from the same brackish water pond referred to as "Stagno 1" placed on the coastline of Ligurian Sea, close to Serchio River mouth, Pisa district (Tuscany, Italy) $\left(43^{\circ} 47^{\prime} 39^{\prime \prime} \mathrm{N}, 10^{\circ} 16^{\prime} 4^{\prime \prime} \mathrm{E}\right)$, and were collected during October 2005, with a water temperature ranging from 18 to $22^{\circ} \mathrm{C}$. The samples also contained ciliates such as Sonderia pharyngea, Plagiopyla sp., Copemetopus sp., and Metopus sp. in moderate or low abundance. In the sediment layer, where $S$. vorax was mainly discovered, the oxygen level in water was $1-7 \%$; close to the water surface it was 35-66\%. Attempts to cultivate in laboratory $S$. vorax were unsuccessful under full oxygen conditions. The ciliates survived in closed tubes within the original samples for a week, and, sometimes, even longer; thus, all investigations were performed on the specimens of the non-clonal neotype population of the original pond, taken from all of the three collected samples.

\section{Live observations}

Live ciliates were observed for morphological details using differential interference contrast (DIC) microscopy with a Leitz (Weitzlar, Germany) microscope at a magnification of 300-1250 $\times$ with the help of a compression device [26]. For examination of the swimming behavior, ciliates were observed in a glass depression slide $(3 \mathrm{ml})$ under a dissection microscope (Wild M3, Switzerland) at a magnification of $12.5-50 \times$.

\section{Fixation and staining}

Ciliates were fixed with Champy's solution [27] and then silver nitrate-stained according to Corliss, 1953 [28]. Feulgen staining procedure after fixation in Bouin's fluid [27] was used to reveal the nuclear apparatus.

\section{Cell image capturing and measurements}

Computer images were captured from appropriate preparations with a digital camera (Canon PowerShot S45), automatically saved as files during optical observation at a magnification of 500-1250 $\times$, and used to obtain measurements of living and fixed ciliates.

Schematic line drawings were based on micrographs of typical living and impregnated cells.

\section{Electron microscopy}

Scanning electron microscope (SEM) and transmission electron microscope (TEM) preparations were obtained as described in Modeo et al. [29] except for: 1. cell preservation in $2 \%(\mathrm{w} / \mathrm{v}) \mathrm{OsO}_{4}$ in distilled water for SEM procedure; 2. use of $2.5 \%(\mathrm{v} / \mathrm{v})$ glutaraldehyde in $0.1 \mathrm{M}$ cacodylate buffer, $\mathrm{pH} 7.4$, for TEM fixation.

\section{Fluorescence microscopy}

Fluorescence microscopy to check the possible autofluorescence of cells due to the presence of methanogenic symbionts was used [30,31]. Specimens were fixed either in $4 \%(\mathrm{v} / \mathrm{v})$ formaldehyde in PBS or in $2 \%(\mathrm{w} / \mathrm{v})$ $\mathrm{OsO}_{4}$ in distilled water, and then observed at the following wavelengths: $495 \mathrm{~nm}, \sim 550 \mathrm{~nm}$, and UV, with both a Zeiss AxioPlan fluorescence microscope (Carl Zeiss, Oberkochen, Germany) equipped with a HBO 100W/2 mercuric vapor lamp, and a Leica DMR microscope (Leica, Switzerland) equipped with a Osram $50 \mathrm{~W} / \mathrm{AC}$ L2 mercuric vapor lamp. With the latter microscope, computer images were captured from appropriate preparations by means of a dedicated software called IM1000, version 1.0. 
To roughly classify ectosymbionts and possible endosymbionts harbored by $S$. vorax double fluorescence in situ hybridization (FISH) experiments were performed according to Ferrantini et al. [32]; the oligonucleotidic probes EUB338 5'-GCTGCCTCCCGTAGGAGT-3' [33], targeting most of Eubacteria, and Arc915R 5'-GTGCTC CCCCGCCAATTCCT-3' [34], specific for Archaea were used.

\section{S rRNA gene sequence obtainment}

Approximately 50 organisms were individually harvested from the original sample and carefully washed three times in sterilized distilled water in order to minimize contaminations from the original medium. The washed cells were fixed in ethanol 70\%. Total genomic DNA was isolated with the NucleoSpin ${ }^{\text {TM }}$ Plant II DNA extraction kit (Macherey-Nagel) and stored at $-20^{\circ} \mathrm{C}$ in aqueous solution.

A polymerase chain reaction (PCR) was performed with a Primus 96 plus thermal cycler (MWG-Biotech AG) employing the TaKaRa Ex Taq (TaKaRa Bio Inc.) (forward primer: 18S F9 Euk [35]; reverse primer: 18S R1513 Hypo [36]; annealing temperature: $50^{\circ} \mathrm{C}$ ). The PCR products were sequenced in both directions using three internal primers as in Rosati et al. [37]. The three partially overlapping sequences were compared to each other and assembled.

\section{Sequence availability and phylogenetic analyses}

The characterized sequence is available under the accession number [EMBL: HF547270].

The 18S rRNA gene sequence of the ciliate was aligned against those available in the SILVA 108 database [38] using the Fast Aligner algorithm of the ARB software package [39]. The alignment was then manually edited in order to optimize base-paring in the predicted rRNA stem regions. For phylogenetic analyses, gaps were coded as a fifth character, while missing data were discarded. Columns containing only one non-gap character were also discarded. The final character matrix contained 40 sequences (29 from the class Plagiopylea and 11 from the class Prostomatea as outgroup) and 1345 columns. The evolutionary model that fits best the data was selected according to the AIC parameter as calculated by jModelTest $[40,41]$. The TREE-PUZZLE [42] Likelihood Mapping function was employed in order to check the informational content of the data.

Phylogenetic analyses were performed with Maximum Likelihood (ML) and Bayesian Inference (BI) methods. The software PHYML [40] as provided by ARB was employed for ML, producing 1000 pseudoreplicates for bootstrapping. MrBayes 3.1.2 [43] was employed for BI, using three different runs with one cold and three heated chains each, running for 1,000,000 generations.
The tree topology was also compared against those obtained from modified character matrices. These were generated: (1) retaining only columns with at least one non-gap character conserved in at least $30 \%$ of the sequences (modified matrix 1); (2) additionally deleting all columns containing gaps (modified matrix 2); (3) removing the sequences of uncultured organisms (modified matrix 3).

\section{Results}

\section{General morphology}

Cells are ovoid-ellipsoid in shape with anterior and posterior ends almost equally curved (Figures 1, 2B, 3A, 3B, 4, $5 \mathrm{~B}, 5 \mathrm{D})$. The body is dorsoventrally flattened. In vivo dimensions are 100-150 × 50-75 $\mu \mathrm{m}(130 \times 69 \mu \mathrm{m}$ on average); dimensions after fixation in Champy's solution are $\sim 80-130 \times 45-70 \mu \mathrm{m}(\sim 113 \times 65 \mu \mathrm{m}$ on average $)$ (Table 1). After SEM treatment, cell dimensions are $\sim 89 \times 42 \mu \mathrm{m}$ on average (Figures $5 \mathrm{~A}, 5 \mathrm{~B})$. The cell surface is uniformly ciliated with 45-62 somatic ciliary rows $(\sim 54$ on average). On the dorsal side $25-31$ rows ( 28 on average) run parallel to each other extending to the posterior end of cell (Figures 3B, 4B, 5B). The dorso-lateral striated band at the right cell margin is visible with DIC microscope as well as on impregnated specimens, arising near the right side of the oral cavity cleft and terminating near the posterior end of the cell (Figures 3B, 4). This structure, that can be considered as a border between dorsal and ventral sides (Figures 1A, 1D, 3A, 3B, 3D, 4), is $\sim 2 \mu \mathrm{m}$ high at SEM, with $\sim 0.5 \mu \mathrm{m}$-spaced out, ridge-like lamellae $\sim 0.15 \mu \mathrm{m}$ in thickness each (Figure 5F). A single contractile vacuole, apparently without collecting canals, is located in the posterior part of cell and opens on the dorsal side (Figure 1E); its pore was not clearly impregnated with silver staining procedure.

On the ventral side, the oral cavity opening is subapically located as a cleft orientated perpendicularly to the main body axis (Figures 1A, 1B, 3A, 5A). The oral ciliature arises from and is in continuity with the somatic ciliature (Figures 5A, 5C). It runs on the dorsal side (upper oral lip) at first perpendicularly to the front of oral cleft; then, it deviates under some angle to the left reaching the oral cavity's deepest point (Figures 1A, 1C). The oral ciliature of the lower oral lip consists of kineties perpendicularly inserted with respect to the upper oral lip kineties and forms single ciliary rows with a membranelle-like appearance at SEM (distance between two ciliary rows: $\sim 0.3 \mu \mathrm{m}$; length of cilia: $\sim 5 \mu \mathrm{m}$ ) (Figure $5 \mathrm{C}$ ). The oral ciliature is represented by 25-30 prebuccal (on the upper oral lip) and 18-20 postbuccal (on the lower oral lip) densely packed kineties. The depth of oral cavity is always not more than $1 / 3$ of body length. On the ventral side, the ciliate kinetom (20-31 ciliary rows, $\sim 28$ on average) consists of two distinct parts: the ventro-lateral kineties (8-13 

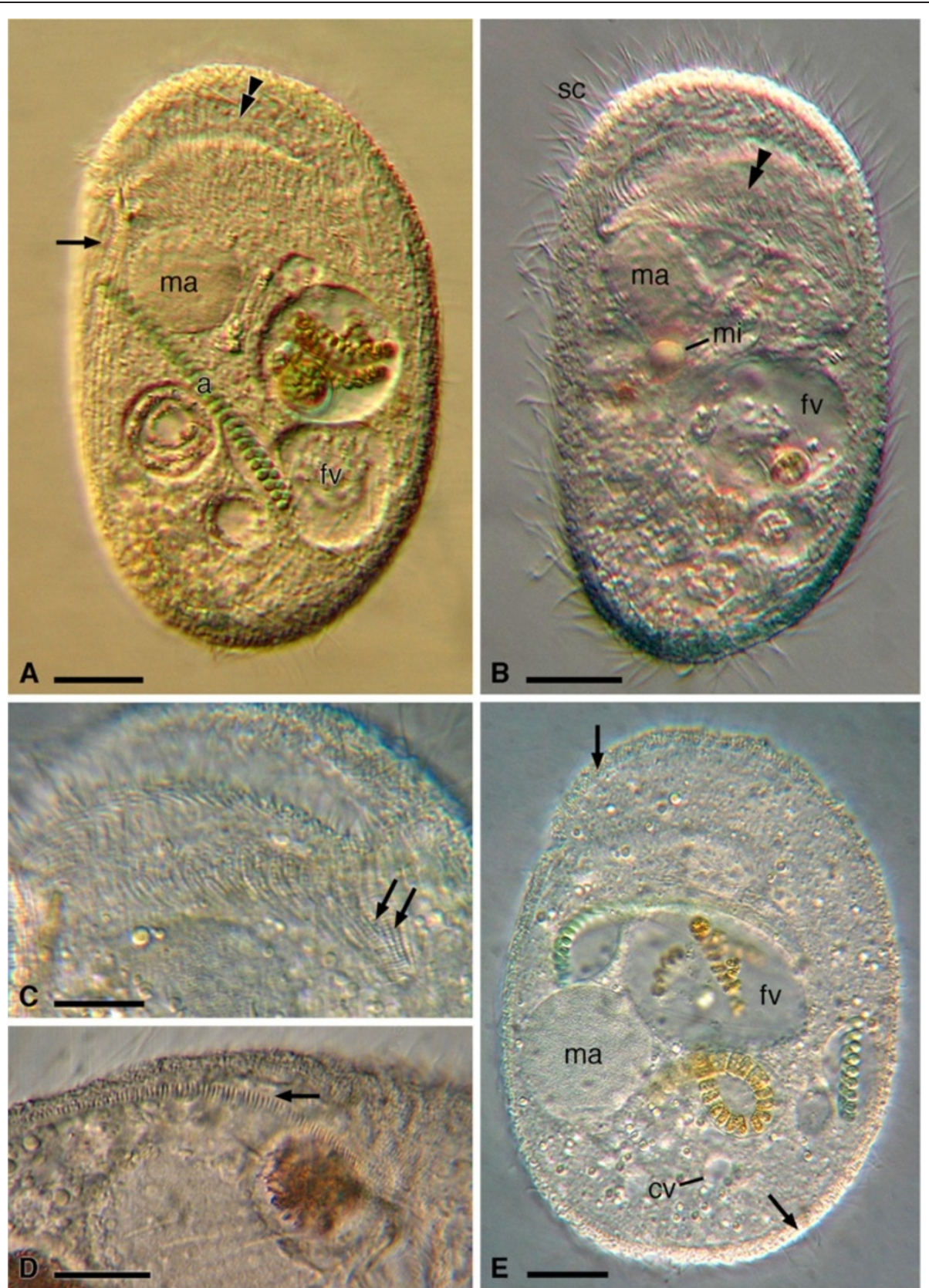

Figure 1 Living observations on Sonderia vorax: general morphology. A. Ventral view. Part of striated band (arrow), the macronucleus, a food vacuole, and the oral opening (double arrowhead) are visible. S. vorax is a algae consumer. B. Ventral view with focus on oral cavity (double arrowhead) and somatic ciliature. C. Dorsal view on the ciliate with focus on oral ciliature within the oral cavity (double arrow). D. Lateral view of the ciliate with emphasis on striated band (arrow). E. Dorsal view showing the layer of ectosymbiotic bacteria (arrow). Abbreviations: a, algae; CV, contractile vacuole; fv, food vacuole; ma, macronucleus; mi, micronucleus; sc, somatic ciliature. Scale bars $=20 \mu \mathrm{m}(\mathbf{A}, \mathbf{B}, \mathbf{E}), 10 \mu \mathrm{m}(\mathbf{C}, \mathbf{D})$.

ciliary rows, $\sim 11$ on average), which are continuous along the cell body, and the ventro-frontal kineties (12-18 ciliary rows, $\sim 17$ on average), which are not continuous (Figure 4A); they start after the membranelle-like ciliary rows and end posteriorly where they meet the left ventro-lateral kineties, forming the so-called ventral secant system [9]; 4-5 rows of the latter group start from the left margin of oral cleft (Figures 3A, 4A).

Many $\sim 20 \mu \mathrm{m}$ long, slightly curved, needle-shaped extrusomes are present in the cortex (Figures 2C-E). They are mainly distributed around the oral cavity opening, but can be found in any part of the cortex and in the cytoplasm. During ejection they appear as long filaments (length at 

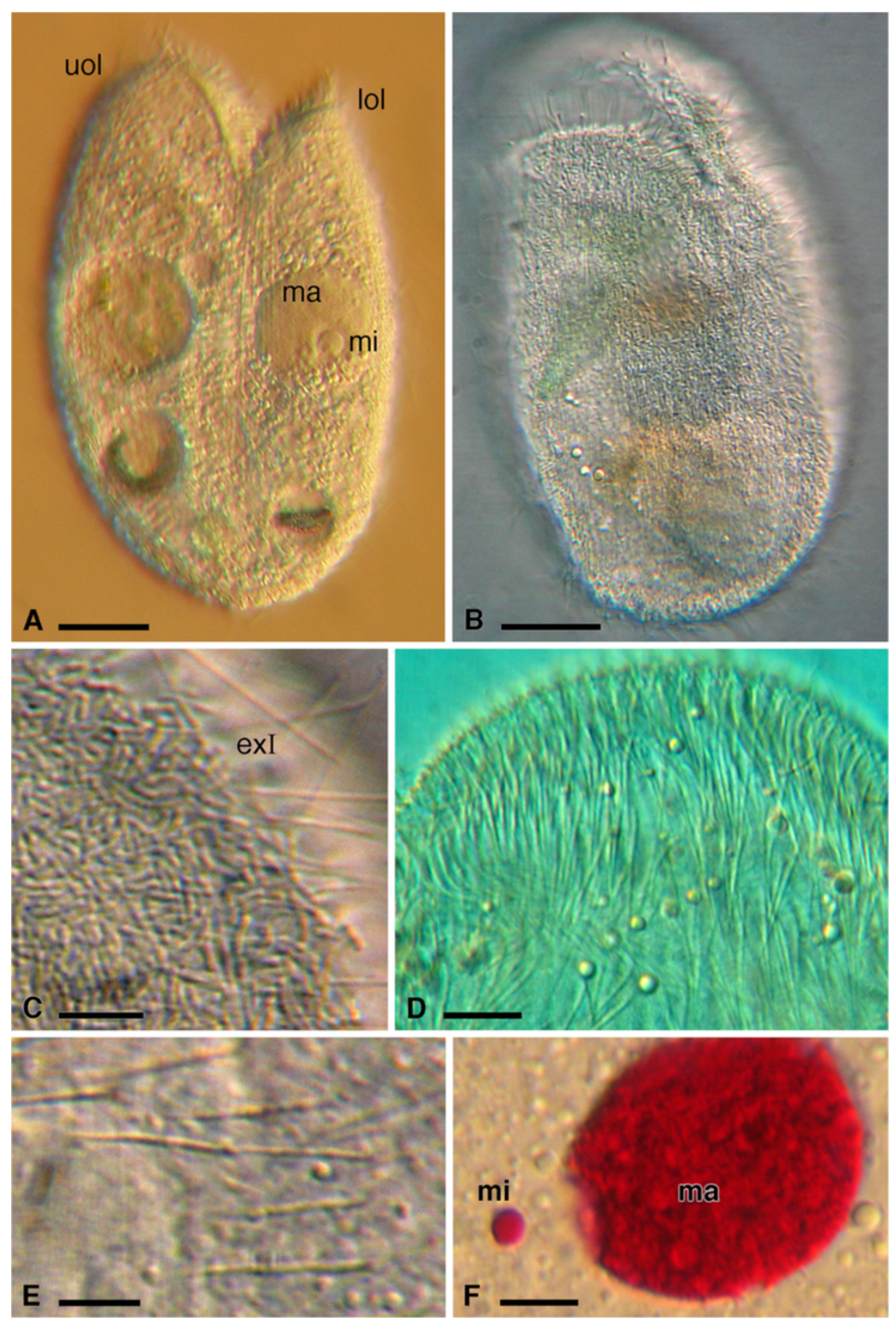

Figure 2 Living observations on Sonderia vorax: some morphological characters. A. Cell view from the right side of oral opening. B. Cell view from the left side of oral opening. $\mathbf{C}$. Extruding longer type extrusomes. D. Anterior part of the cell with a number of resting longer type extrusomes. E. Resting longer type extrusomes at higher magnification. F. Nuclear apparatus after Feulgen staining. Abbreviations: exl, longer type extrusomes; lol, lower oral lip; ma, macronucleus; mi, micronucleus; uol, upper oral lip. Scale bars $=20 \mu \mathrm{m}(\mathbf{A}, \mathbf{B}), 10 \mu \mathrm{m}(\mathbf{C}, \mathbf{E}, \mathbf{F}), 15 \mu \mathrm{m}(\mathbf{D})$.

SEM: $17 \mu \mathrm{m})$ (Figure 5D). A single quite large micronucleus (diam: $5.4 \mu \mathrm{m}$ on average) of the compact type is situated nearby or inside the depression of the almost spherical macronucleus $(27 \times 32.5 \mu \mathrm{m}$ on average) (Figure 2F). The cell surface is covered by a layer of slightly curved, rod-shaped ectosymbiotic bacteria (size at
SEM: 1.5-3.0 $\times 0.3-0.5 \mu \mathrm{m})$, arranged in parallel rows along interkinetal spaces (interkinetal space thickness at SEM: $2.3 \mu \mathrm{m}$ ) (Figures 1E, 3C, 3D, 5C, 5E) except for striated band (Figures 3D, 5F). At SEM observation no gelatinous or mucous coating between the layer of bacteria and ciliate surface was detected (Figure 5). 

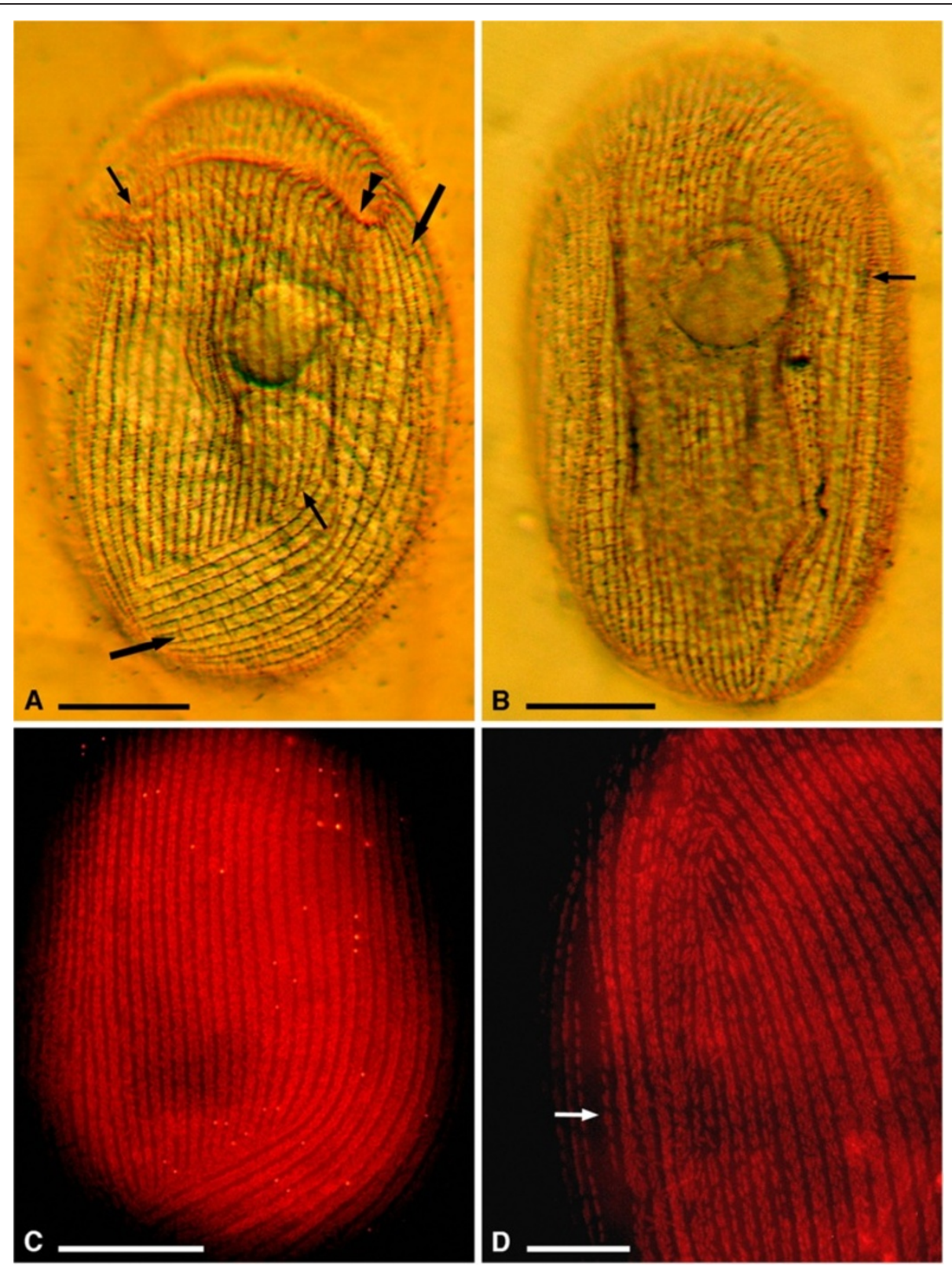

Figure 3 Kinetom peculiarities of Sonderia vorax from silver nitrate impregnated specimens (A, B) and under fluorescent microscopy after FISH reaction (C, D). A. Ventral kinetom consists of two parts: the central ventro-frontal part, where kineties interrupt posteriorly (arrows), and the left ventro-lateral part consisting of continuous kineties (larger arrows). The border between the first and the second part at the left side of oral opening is indicated by the double arrowhead. B. Dorso-lateral kinetom. The striated band (arrow) reaches the last third of ciliate body. C. Ventral view of a cell after FISH (probe EUB338), highlighting the covering of ectosymbionts. D. Right part of ciliate ventro-lateral surface after FISH (probe EUB338) with numerous ectosymbiotic bacteria distributed along kineties. Arrow points at striated band uncovered by ectosymbiotic bacteria. Scale bars $=25 \mu \mathrm{m}(\mathbf{A}-\mathbf{C}), 10 \mu \mathrm{m}(\mathbf{D})$.

\section{Notes of behavior}

Specimens of Sonderia vorax rotate on the main body axis always anticlockwise (i. e. cells are left spiral swimmers). This species inhabits brackish water sites with oxygen deficiency (oxygen level 1-7\%) and is mainly a consumer of diatoms and other algae.

\section{TEM observation}

\section{Cell surface and cortex}

The surface of Sonderia is furrowed by deep longitudinal depressions separated by sharp ridges. Two rows of the rod-shaped ectosymbiotic bacteria (size: 1.5$4.3 \times 0.3-0.8 \mu \mathrm{m}$ ) lay in each furrow mostly with their 


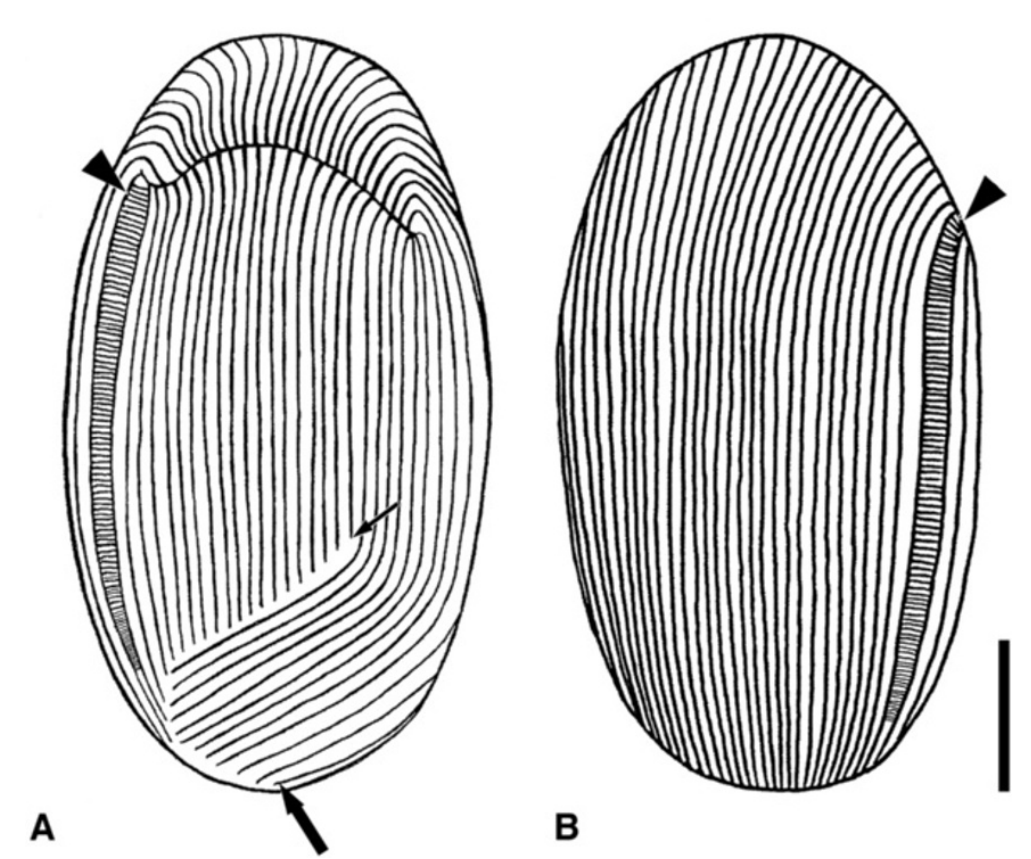

Figure 4 Schematic line drawing showing the kinetom of Sonderia vorax according to living and silver nitrate impregnated cells. A. Ventral view. B. Dorsal view. The ventro-frontal (larger arrow) and the left ventro-lateral kineties (arrow) fields as well as the striated band (arrowhead) are indicated. Scale bar $=20 \mu \mathrm{m}$.

long axis parallel to the cell surface. Two membranes delimit their dense, uniform cytoplasm that, only rarely, contains white spots. The outermost membrane is wavy and shows protruding small vesicles. In some spots it is in direct contact with host cell membrane; in some cases the irregular outline of the bacteria appears to be perfectly accommodated by irregularities in the host membrane. Where bacteria are present, the ciliate cortex forms small depressions in which vesicles are often visible (Figure 6A). Occasionally, a very thin layer of slightly dense material is barely visible between bacteria and ciliate surface (Figures 6A, 6B, 7B).

In the cortex the plasma membrane and the outer alveolar membrane are strictly associated and appear to originate from the well-developed, irregular, alveolar space. In the latter a homogeneous, dense material is always present. The inner alveolar membrane is underlined by a $40-50 \mathrm{~nm}$ thick dense layer (epiplasm) (Figure 6B). Longitudinal bundles of subcortical microtubules are present along the surface of the cortical ridges (Figure 6C).

\section{Somatic ciliature}

The kineties are composed of monokinetids inserted at the top of the cortical ridges. Kinetosomes are relatively large and $\sim 1 \mu \mathrm{m}$ long. They display a terminal plate and a secondary terminal plate in apparent continuity with the epiplasm, and often contain a dense body (Figures $6 \mathrm{~B}, 7 \mathrm{~A})$. The somatic monokinetids have typical fibrillar associates (Figures 6A, 7A-C): a kinetodesmal fibril extending to overlap the kinetodesmal fibrils of anteriormost monokinetids; the postciliary ribbon; a short transverse ribbon originating at the opposite side of the kinetosome with respect to postciliary microtubules.

\section{Extrusomes}

Numerous, prominent extrusomes are distributed between the kineties. They are very long, slightly curved rods, $0.6 \mu \mathrm{m}$ in diameter. The longest longitudinal section we obtained (Figure 7D) is $9.7 \mu \mathrm{m}$ but, as revealed by in vivo/ SEM observation, they are certainly longer. Although the distal region of these extrusomes is differently organized with respect to the main part of the organelle, a distinct "tip" is not present (Figures 7A, 7E, 7F). Internally to their membrane an electrondense sheet covers a thin, granular layer of variable density that, in turn, surrounds a continuous dense core in which we were not able to evidence a periodicity. In cross sections this core shows a somehow squared section (Figure 7E); it maintains the same size $(\sim 0.5 \mu \mathrm{m})$ for the whole length of the organelle except at the distal region level where it is pointed and enveloped by the granular layer (Figure 7F). Then, a material with apparently the same electrondensity of the core forms a sort of hood. At this level three different layers are present and clearly evident in sections. Starting from the membrane they are: the hood, the granular layer, and a thin portion of the core (Figures 7A, 7F, 7G). When the extrusomes are 


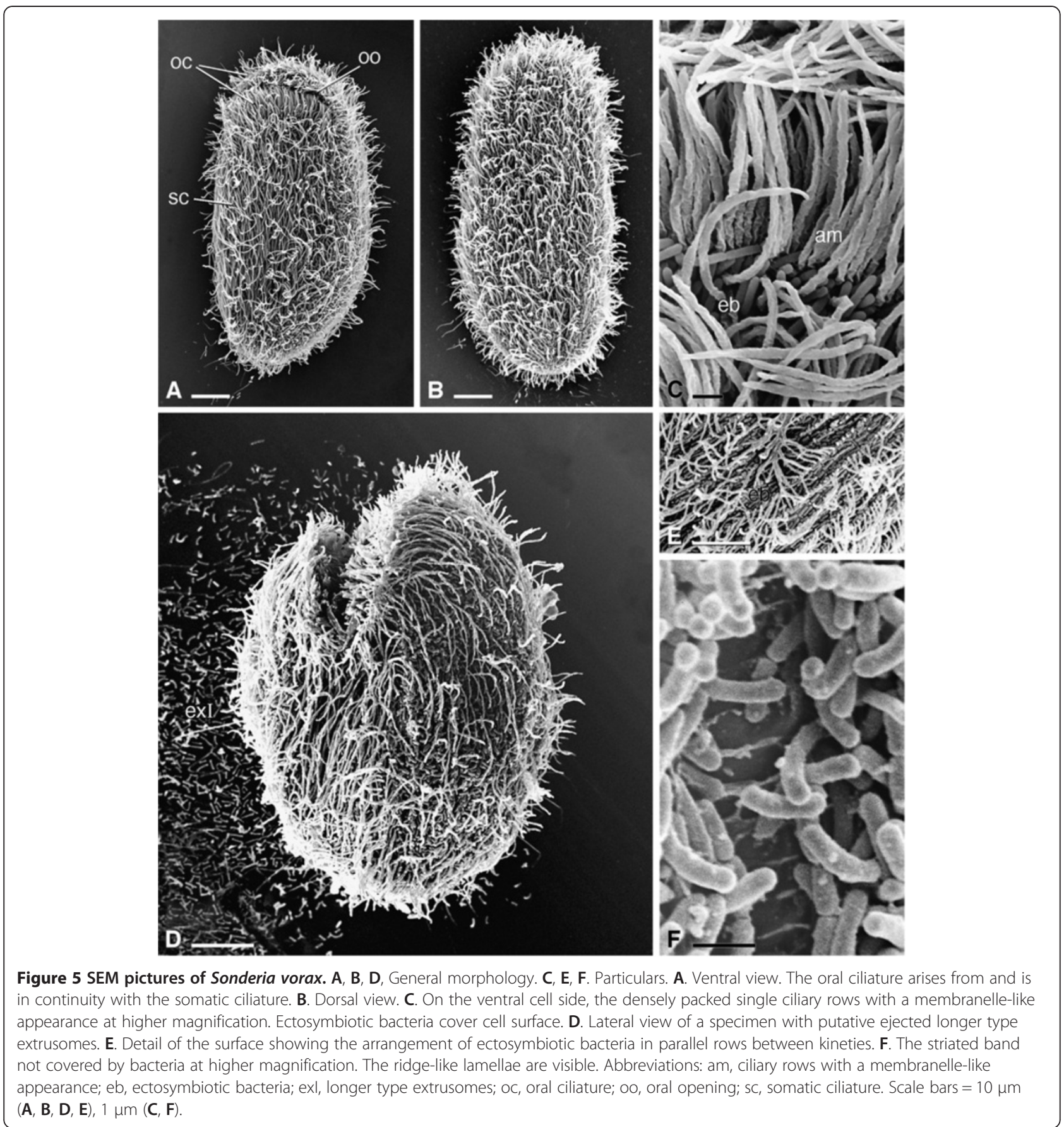

positioned right beneath the plasma membrane in docking sites between the alveoli, a clear layer forms the distal end of the structure (Figure 7G). The extrusomes originate deeply in the cytoplasm. A stage of this extrusome development is shown in Figure 7H.

A second, different kind of extrusome, smaller $(\sim 2 \times 0.2 \mu \mathrm{m})$ and less differentiated than that described above, is also visible (Figure 7G inset). Unfortunately in TEM preparations we never observed any type of extrusome ejected or during ejection process.

\section{Oral zone ciliature}

The ciliature of the upper oral lip is continuous with the somatic kineties, but the cilia are inserted in less pronounced cortical ridges perpendicularly to the body long axis (Figure 8A). They are connected at the basal bodies (Figure $8 \mathrm{~B}$ ). The kineties of the ciliature of the lower oral lip are perpendicularly inserted with respect to those of the upper lip. They form densely packed single ciliary rows with a membranelle-like appearance (Figure 8A). The kineties of the oral lips do not have 


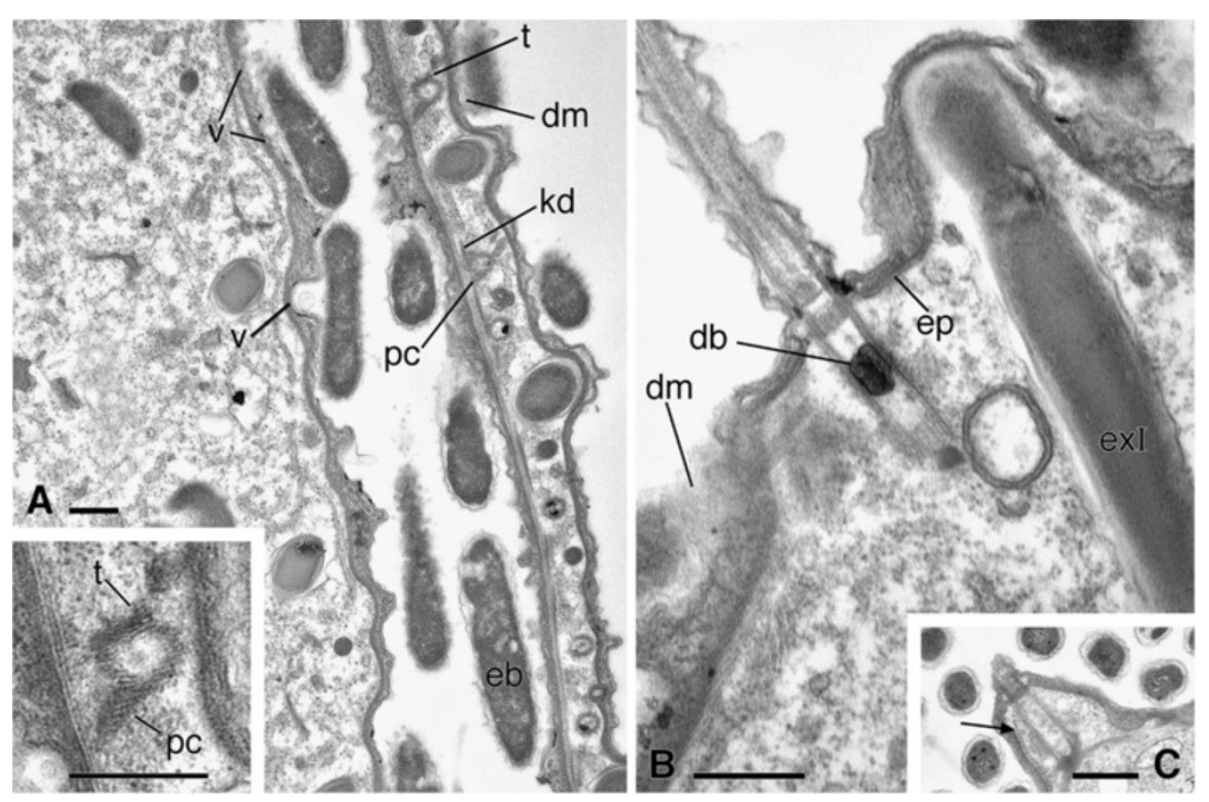

Figure 6 TEM pictures of Sonderia vorax: cell surface, cortex, and somatic ciliature. A. Ectosymbiotic bacteria cover the cell surface. Vesicles inside small cortical depressions are found in correspondence with ectosymbiotic bacteria. Slightly dense material is occasionally observed between ectosymbiotic bacteria and ciliate surface. Roots of monokinetids are visible: the kinetodesmal fibril, the postciliary microtubules, and the transverse microtubules. A Inset. Enlargment of a monokinetid root. B. The thick, dense epiplasm under the cortex; a dense body is visible inside somatic monokinetids. C. Bundles of subcortical microtubules (arrow). Abbreviations: db, dense body; dm, dense material; eb, ectosymbiotic bacteria; ep, epiplasm; exl, longer type extrusomes; kf, kinetodesmal fibril; pc, postciliary microtubules; $t$, transverse microtubules; $v$, vesicles. Scale bars $=0.5 \mu \mathrm{m}$

kinetodesmal fibrils nor postciliary and transverse microtubules. Notwithstanding their different organization, in both the upper and the lower oral lips a complex system of fibres interconnects the adjacent oral kineties and the kinetosomes within each kinety (Figures 8A, 8E). Deeply in the oral zone, a bundle of cilia arises on the lower lip, perpendicularly oriented with respect to the membranelle-like ciliary rows but connected with them by the same complex fiber system. It extends towards the cytostomal region, i.e. where the cortex is interrupted and the zone delimited by the simple plasma membrane begins (Figure 8D). Pharyngeal disks-like structures are present in the cytoplasm surrounding this zone (Figures $8 \mathrm{C}, 8 \mathrm{D}$ ).

\section{Cytoplasm}

The cytoplasm is rich in ribosomes; cisternae and tubules of endoplasmic reticulum are abundant. Well formed or developing extrusomes can be found in different cytoplasmic regions. Various hydrogenosomes-endosymbiotic bacteria assemblages, where partners alternate for position, can be observed throughout the cytoplasm in the neighbourhood of endoplasmic reticulum elements (Figures 9A-C, 9E). On the base of previous papers showing the presence of similar associations in relative genera (see Discussion), we recognized hydrogenosomes as very electron dense, double membrane bounded organelles, with a granular matrix and an irregular shape; sometimes they appeared more similar to rods (dimensions: $\sim 2.0 \times 0.2 \mu \mathrm{m})$, sometimes they appeared as flattened disks (Figures 9A, 9B). No enfoldings of the inner membrane were detected within hydrogenosomes. The endosymbiotic bacteria (size: $\sim 2.0 \times 0.6 \mu \mathrm{m}$ ) are not enclosed by a ciliate-derived membrane and are often irregularly shaped. Both hydrogenosomes and bacteria, but more often the latter, are found at the ends of assemblages (Figures 9A-C, 9E); the assemblages sometimes appear to be somehow in intimate association with endoplasmic reticulum (Figure 9). Occasionally a smaller, denser, rodshaped type of bacteria (width: $\sim 0.1-0.2 \mu \mathrm{m}$ ) is visible in contact with hydrogenosomes (Figures 9B, 9C). Only in a few cases hydrogenosomes not associated with endosymbionts are observed strictly under the cortex, near to the ectosymbiotic bacteria (Figure 9D).

Very large food vacuoles, containing a variety of ingested material, occupy most of the internal cytoplasm (Figure 9E). Polysaccharide reserve substances are in the form of large paraglycogen granules (Figure 9F); lipid droplets are also present.

\section{Nuclei}

In stationary phase, macronuclear chromatin forms small condensed bodies, in which numerous, conspicuous 


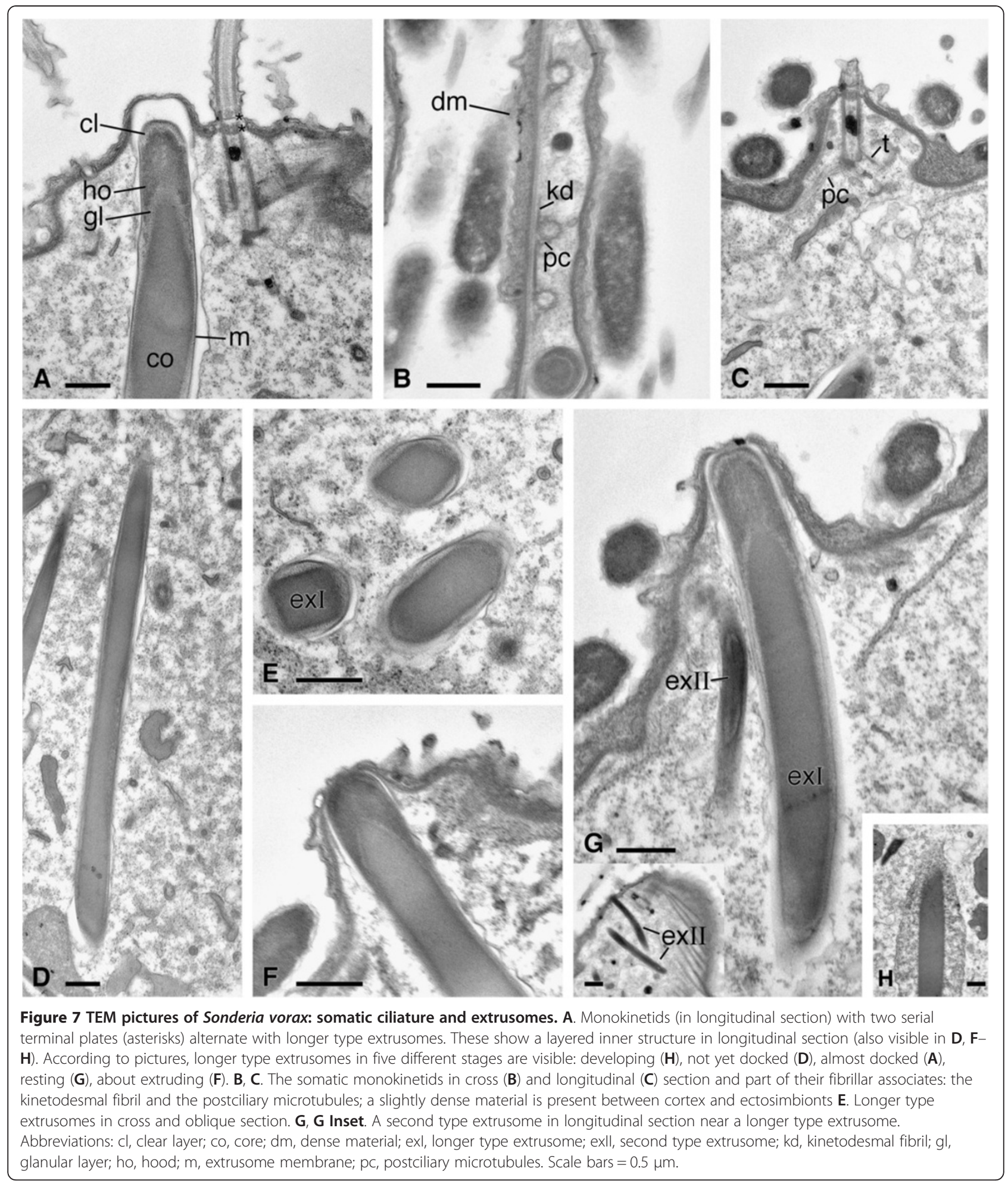

nucleoli are dispersed. The micronuclear chromatin is organized in a dense meshwork of branched bodies, thinner than those in the macronucleus. The chromatin occupies most of the nuclear centre and is separated from the nuclear envelope by a narrow rim of karyolimph (Figure 9F).

\section{Fluorescence microscopy observation}

Cells observed after treatments do not autofluoresce (data not shown). Neither endo- nor ectosymbiotic bacteria are labeled by archeal specific probe Arc915R (data not shown). Ectosymbionts are marked by the universal 


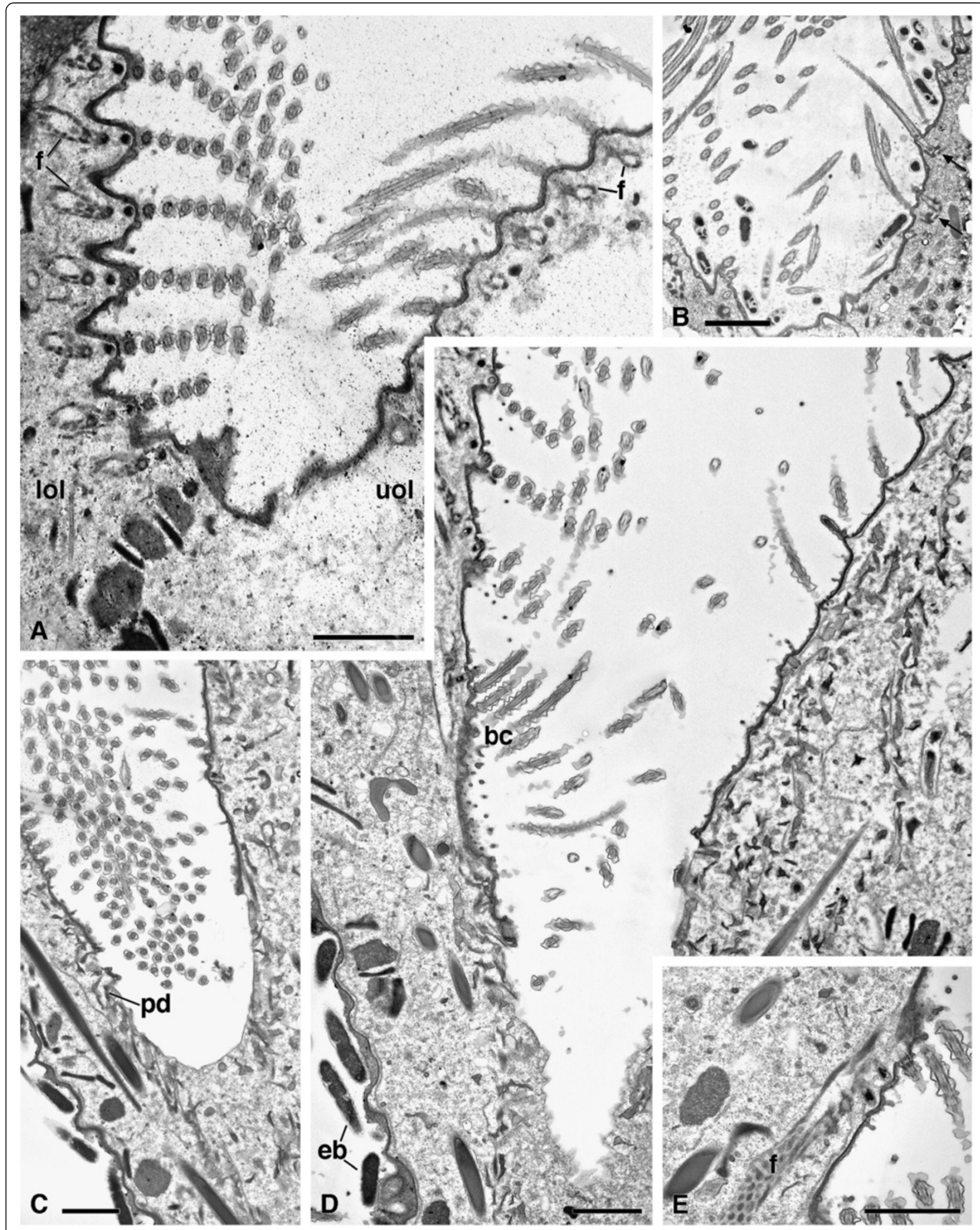

Figure 8 (See legend on next page.) 


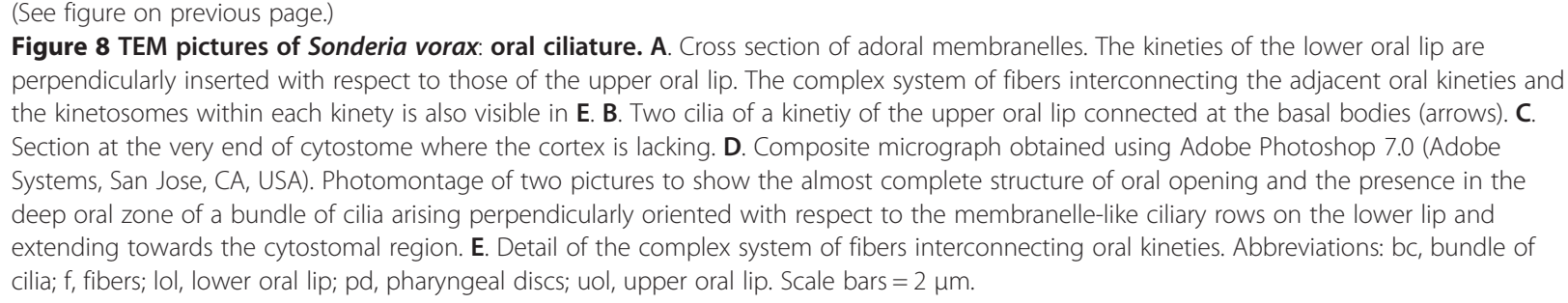

eubacterial probe EUB338 (Figures 3C, 3D): since they cover most of the cell surface, it is not possible to discriminate signals arising from endosymbionts possibly labelled by the same probe.

\section{Phylogenetic analysis}

The ML tree is shown in Figure 10. With one significant exception discussed below, the topology of the ingroup is almost identical in all trees calculated.

Inside class Plagiopylea, the clade containing Epalxella antiquorum (Odontostomatida, Epalxellidae) and four related environmental sequences is the sister group of a major cluster containing all the taxa of the order Plagiopylida. These are distributed in the Trimyemidae clade with three morphospecies of the genus Trimyema, the Plagiopylidae clade including the genera Plagiopyla (non monophyletic) and Lechriopyla, and the Sonderiidae clade with the sequences of S. vorax and Parasonderia vestita. All the aforementioned clades also include environmental sequences from freshwater and marine environments, either suboxic or anoxic. The five sequences most closely related to that of $S$. vorax were obtained from the supersulfidic and anoxic Framvaren Fjord (Norway).

The monophyly of the families Plagiopylidae and Trimyemidae is well supported. The status of family Sonderiidae is more dubious. It appears monophyletic when trees are calculated either on the unmodified character matrix or the modified matrix 1 , although with low statistical support (62/0.75 and 60/0.75 respectively); the support is higher (97/1.00) when sequences from uncultured organisms are discarded (modified matrix 3). In trees calculated on the modified matrix 2 , the $P$. vestita sequence and the closely related environmental sequences AB505461 cluster with Plagiopylidae instead, again with low support (72/0.76).

\section{Discussion}

Identification of our population as Sonderia vorax Kahl, 1928 and comparison with related species

Up to now 10 species of Sonderia have been described, most of them by Kahl (8 species) [1,11]. Four of the originally described Sonderia species were transferred to three different genera [15]: Oncosonderia (Sonderia tubigula); Parasonderia (Sonderia cyclostoma and Sonderia kahli); Kahlisonderia (Sonderia mura). Currently the genus consists of seven species, but the species composition is definitely different with respect to that originally proposed by Kahl. An additional species, Sonderia vestita (Parasonderia vestita according to $\mathrm{Xu}$ et al. [16]), still has an uncertain position. The main features of that ciliate do not resemble those of Parasonderia kahli, designated as the type species for its genus [14,15], so that Jankowski [15] proposed to keep it as $S$. vestita following Kahl [11]. Finally, the new species Sonderia paralabiata [44] has never been properly described; the only distinctive feature provided by the authors designates the arrangement of kinetids in groups of 3-5 kinetosomes. This is in contradiction with the later statement of Lynn [12] that "the somatic kinetids are monokinetids in the sonderiids, plagiopylids, and trimyemids". Nevertheless, 3 other sonderiids - S. vestita, Sonderia labiata, S. paralabiata, and maybe Sonderia sinuata, with di- and even up to pentakinetids in the somatic ciliature have been reported $[4,5,16,44]$.

Most of the descriptions of Sonderia spp. did not include silver impregnation and other staining methods, and were based upon only a few morphological markers, which sometimes could not provide easy discrimination between the ciliates (Table 2). Xu et al. [16] stated that "the oral structure [...] is one of the most important diagnostic characters of genera within the family Sonderiidae", but these data are not yet available for the majority of Sonderia species. Nevertheless our Sonderia fits well the original description and pictures of $S$. vorax in the publications of Kahl $[1,11]$. However, this species has never been reinvestigated with modern analytical tools after the original isolation from marshes in Oldesloe (1928) and in the Island of Sylt (1931). Thus, some of the distinctive characteristics of the ciliate which were not mentioned in the original description [1] are lacking (see Table 2).

S. vorax can be easily separated from some of the similarsized species, $S$. pharyngea and S. labiata, because these ciliates do not show a differentiation of ventral kinetom, the so-called secant system [9] (Table 2). On the contrary, this feature is probably shared between $S$. vorax and $S$. sinuata [9], although it has not been indicated neither by Dragesco \& Dragesco-Kernéis [4] nor by Al-Rasheid [45]. 


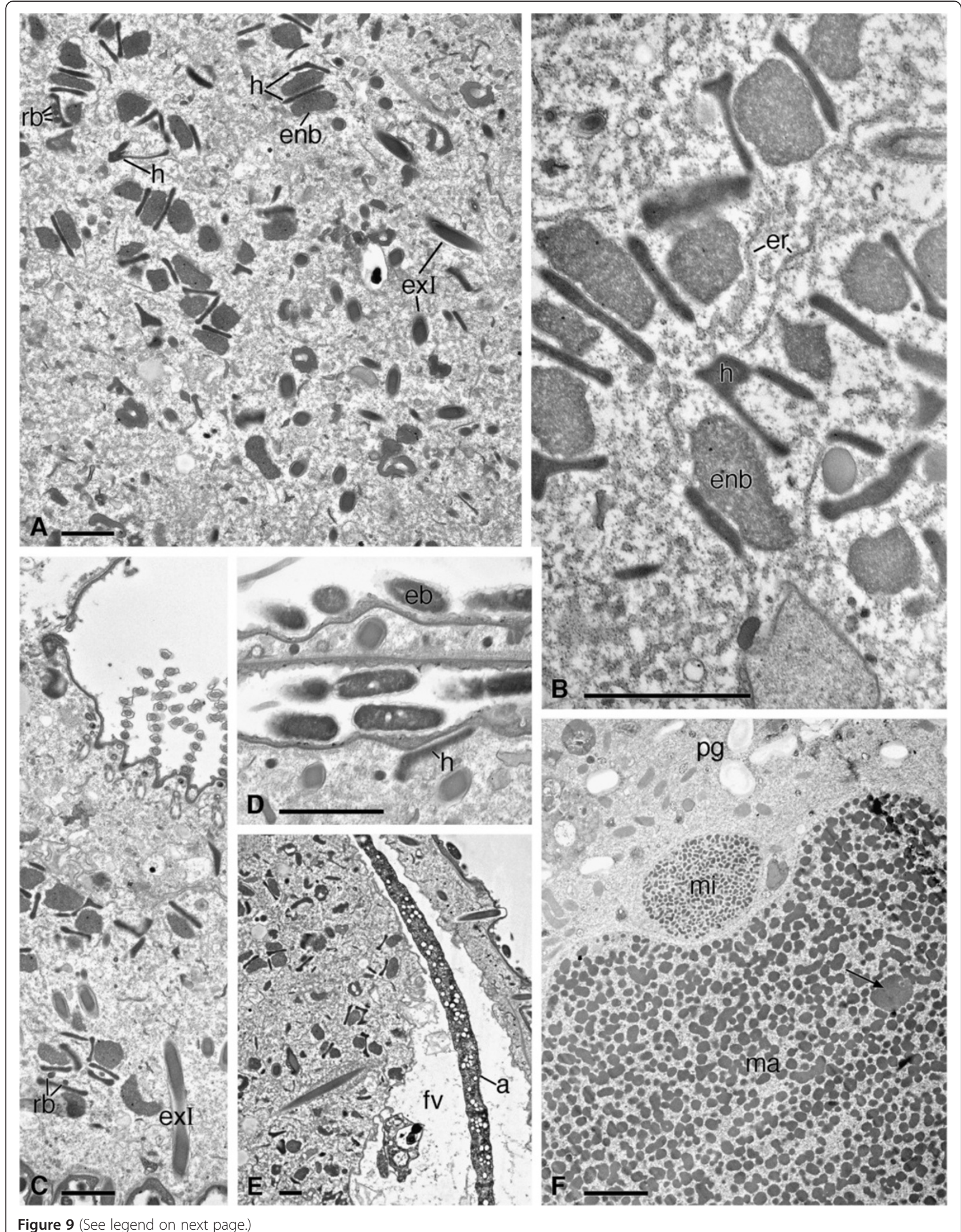


Anyway, S. vorax differs from S. sinuata for: cell size (180$240 \mu \mathrm{m}$ vs. $100-150 \mu \mathrm{m})$; buccal cavity size (1/2 of cell body $v s .1 / 3$ of cell body); number of dorsal kineties (45 vs. 25-31); size (and probably structure) of the micronucleus [4,9] (Table 2). The oral ciliature consists of monokinetids in $S$. vorax while some contradictions do exist in the literature for $S$. sinuata $[4,9]$.

\section{General remarks on SEM and TEM analyses}

Papers dealing with SEM and TEM observation on the complete cell structure of order Plagiopylida are respectively lacking and scarce. Fine structure descriptions of representatives of family Sonderiidae are limited to the data on $S$. vorax and Sonderia sp. reported by Fenchel et al. [46], in a study on the interaction between those ciliates and other marine organisms (the so-called "sulphide fauna") and their prokaryote symbionts. As general information about the determination of their species are lacking, on the basis of the few TEM pictures and data supplied, we could just state the congenerity of our species with $S$. vorax studied by those authors, but nothing could be argued concerning their conspecificity. Beside the comparison with TEM data reported by Fenchel et al. [46], we also took the opportunity to shed light on general ultrastructure of Plagiopylida; thus, we made a larger comparison with available data on plagiopylid genera such as Lechriopyla and Plagiopyla [30,47-53], as well as on the single trimyemid genus Trimyema $[19,23,51,54,55]$.

\section{SEM observation and ectosymbionts}

Ectosymbiotic bacteria somewhat covering the cell surface of ciliates have been widely reported (e.g. [56]). Those borne by the hypotrich Euplotidium spp., referred to as epixenosomes [57,58], are peculiar extrusive symbionts nearly identical at the ultrastructural level to the spherical episymbiotic bacteria of the euglenozoan Bihospites bacati [59], which lives in oxygen-poor habitats. The latter species also bears rod-shaped ectosymbiotic bacteria; these appear to be widespread in protists living in oxygenpoor habitats, as they have been also described in both flagellates such as Calkinsia aureus [60] and Postgaardi mariagerensis [61] and ciliates such as Parablepharisma spp., Metopus spp., and Sonderia spp. [6,8,11,46,62,63].
In previous papers on Sonderia spp. the presence of a gelatinous coat between the ectosymbiotic bacteria and the ciliate plasma membrane was either reported as clearly visible under light microscope [5,9] or at least supposed [46]. Although ectosymbiotic bacteria covering our species appeared partly aggregated on the slide when detached from the ciliate (Figure 5D), a gelatinous coat between ectosymbiotic bacteria and plasma membrane was not evidenced by SEM, while by TEM only a slightly dense layer of material in a few occasions was observed (see below). This result, an apparent discrepancy between SEM and TEM observation, is also evident in pictures of other papers dealing with protists living in oxygen-poor habitats that bear ectosymbionts underlined by a glycocalyx on their cell surface $[59,60]$.

Curiously, the presence of ectosymbionts as a common feature of the Sonderiidae was not even mentioned in two of the most solid recent ciliate reviews $[12,13]$. However, this could be in our opinion a good morpho-biological feature to discriminate members of Sonderiidae family. The ectosymbionts of $S$. vorax were marked by the universal eubacterial probe in FISH experiments; this indicates their affiliation to Eubacteria.

The height of the striated band on the right surface measured at SEM in S. vorax fits that reported by Lynn [12] in the general description of somatic structures of the families Plagiopylidae and Sonderiidae; thus, we confirmed the size of this structure in sonderiids, but the meaning of this peculiar cortex feature still remains unknown.

\section{TEM observations and endosymbionts \\ Cell surface and cortex}

The bacteria covering the surface of Sonderia spp. described by Fenchel et al. [46] are 1.5-2.5 × 0.35-0.40 $\mu \mathrm{m}$ and are visible within the oral vestibulum but not in the ciliate peristome; the ectosymbiotic bacteria covering the surface of our $S$. vorax share with them this kind of localization but appear slightly longer and wider, and more tidily oriented.

As in other previously described Plagiopylida [47,54], the somatic cortex of $S$. vorax includes a homogeneous, dense alveolar material, of variable thickness. In our opinion, this material could have been interpreted, under the light microscope, as the gelatinous coat reported by 


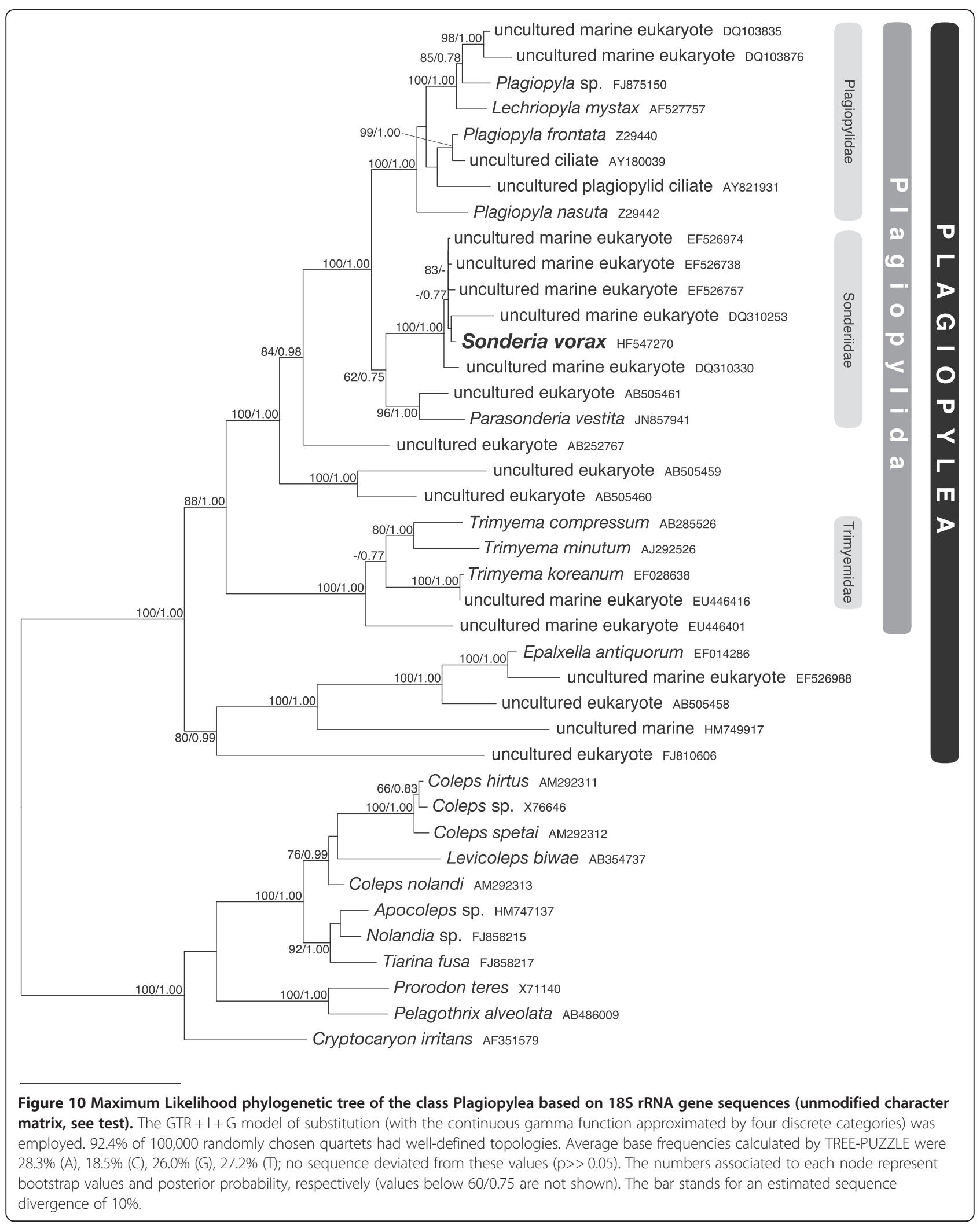


Table 1 Morphometric characterization of Sonderia vorax Kahl, 1928

\begin{tabular}{|c|c|c|c|c|c|c|}
\hline Characteristics & Min & Max & Mean & SD & CV & $\mathrm{n}$ \\
\hline Body, length & 80 & 130 & 113.1 & 12.5 & 11.0 & 12 \\
\hline Body, width & 45 & 70 & 64.9 & 5.4 & 8.3 & 12 \\
\hline Somatic ciliary rows (dorsal), number & 25 & 31 & 28.3 & 2.6 & 9.2 & 17 \\
\hline Somatic ciliary rows (ventro-frontal), number & 12 & 18 & 17.1 & 2.4 & 14.0 & 14 \\
\hline Somatic ciliary rows (ventro-lateral), number & 8 & 13 & 11.4 & 1.8 & 15.8 & 11 \\
\hline Somatic ciliary rows (general), number & 45 & 62 & 54.0 & 4.13 & 7.75 & 20 \\
\hline Prebuccal kineties (upper oral lip), number & 25 & 30 & 27.6 & 2.05 & 7.4 & 3 \\
\hline Postbuccal kineties (lower oral lip), number & 18 & 20 & 19.0 & 1.0 & 5.3 & 3 \\
\hline Macronucleus, length & 25 & 35 & 32.5 & 3.7 & 11.4 & 15 \\
\hline Macronucleus, width & 22 & 34 & 27.0 & 2.7 & 10.0 & 15 \\
\hline Micronucleus, number & 1 & 1 & 1 & 0 & 0 & 20 \\
\hline Micronucleus, diameter & 5.0 & 6.0 & 5.4 & 0.3 & 5.5 & 20 \\
\hline
\end{tabular}

All measurements are in $\mu \mathrm{m}$. Data obtained from silver impregnated or Feulgen stained (nuclear apparatus) specimens. CV, Coefficient of variation in \%; Max, maximum; Mean, arithmetic mean; Min, minimum; $n$, number of specimens investigated; SD, standard deviation.

previous authors $[5,9,46]$. Alternatively, it is possible that the coat could be formed, under particular conditions, by this alveolar material released by means of the vesicles visible inside the small depressions of the cortex of our $S$. vorax where bacteria are localized.

\section{Somatic ciliature}

Kineties of $S$. vorax are composed of monokinetids as is typical of Plagiopylea [12] with the possible exception of Parasonderia vestita according to Xu et al. [16]. Somatic cilia at the tops of cortical ridges in $S$. vorax appear typical of Plagiopylidae in contrast to kinetosome arrangement between the ridges observed in Trimyemidae [12].

Our observations on the kinetid pattern of $S$. vorax fit the interpretation of Lynn [12]: in Plagiopylida the transverse ribbon has a radial orientation on the opposite side with respect to postciliary microtubules and a very short trajectory.

Kinetosomes are longer then those described in Lechriopyla mystax and Plagiopyla minuta by Berger and Lynn [47] $(\sim 1.0 \mu \mathrm{m}$ vs. $0.65 \mu \mathrm{m})$ but those two organisms share with $S$. vorax the presence of two terminal plates. The presence of dense material inside somatic and oral kinetosomes of $S$. vorax was also reported by Detcheva et al. [54] in Trimyema compressum.

\section{Extrusomes}

The longer extrusomes of our species can be considered a novel kind of extrusive organelle so far unknown $[64,65]$. Actually, their complex structure does not fit the definition of mucocysts reported for the class Plagiopylea by Lynn [12], neither if the latter are meant as "elongate and rod-shaped mucocysts" as described for plagiopylids and sonderiids, nor if they are meant as "spheroidal mucoysts" of trimyemids. In particular, the organelles, although similarly distributed (between kinetids of the kineties), appear different in shape and layer organization from extrusomes described by Berger \& Lynn [47]. Neither our longer extrusomes, nor those described by Berger \& Lynn [47], nor the longer extrusomes reported by de Puytorac et al. [53] in Plagiopyla nasuta can be assimilated with classical trichocysts: none of them actually exhibit the typical trichocyst organization in a distal, distinct tip and a larger striated basal portion $[64,65]$. Unfortunately, a comparison with the "large trichocysts" reported in Sonderia sp. (and Plagiopyla frontata) by Fenchel et al. [46] is unfeasible because the authors only evidenced them in a picture without any comment; however, those organelles share with our extrusomes at least the layered inner structure.

Only de Puytorac et al. [53] reported the presence of two kinds of extrusomes in a representative of plagiopylids, i.e. P. nasuta: a first curved type already cited and a smaller, not fully described second type; both of them were, in the authors' opinion, very different from mucocysts. Comparison is not possible between the second type of extrusome we observed by TEM in $S$. vorax and that of $P$. nasuta due to the lack of fine structure details. However, due to their small sizes and low abundance, these organelles could likely be overlooked during former descriptions of Sonderia spp. $[5,9,46]$.

\section{Oral zone ciliature}

The oral kinetosomes of our S. vorax appear typical of Plagiopylida [12].

\section{Hydrogenosomes and endosymbionts}

As expected on the basis of previous ultrastructural studies concerning free-living as well as endocommensal 
Table 2 Comparison between the morphology and morphometry of Sonderia vorax and other similar-sized species of Sonderia according to selected literature data $^{\text {a }}$

\begin{tabular}{|c|c|c|c|c|c|c|c|c|c|c|}
\hline Character & $\begin{array}{l}\text { Sonderia pharyngea } \\
\text { Kirby, } 1934\end{array}$ & $\begin{array}{l}\text { Sonderia labiata } \\
\text { Fauré-Fremiet \& } \\
\text { Tuffrau, } 1955\end{array}$ & $\begin{array}{l}\text { Sonderia } \\
\text { sinuata } \\
\text { Kahl, } \\
1931\end{array}$ & $\begin{array}{l}\text { Sonderia } \\
\text { sinuata } \\
\text { Borror, } \\
1972\end{array}$ & $\begin{array}{l}\text { Sonderia sinuata } \\
\text { Dragesco \& } \\
\text { Dragesco-Kernéis, } \\
1986\end{array}$ & $\begin{array}{l}\text { Sonderia } \\
\text { sinuata Sola } \\
\text { et al., } 1989\end{array}$ & $\begin{array}{l}\text { Sonderia sinuata } \\
\text { Al-Rasheid, } 2001\end{array}$ & $\begin{array}{l}\text { Sonderia } \\
\text { vorax Kahl, } \\
1928\end{array}$ & $\begin{array}{l}\text { Sonderia } \\
\text { vorax Khal, } \\
1931\end{array}$ & $\begin{array}{l}\text { Sonderia vorax } \\
\text { present study }\end{array}$ \\
\hline $\begin{array}{l}\text { cell length, } \\
\mu \mathrm{m}\end{array}$ & 84-110 (IV?) & 160-180 (IV?) & $\begin{array}{l}240-250 \\
\text { (IV?) }\end{array}$ & $145-164$ & 180-240 (IV?) & $132-176$ (OF) & 90-120 (IV?) & 60-150 (IV) & 70-180 (IV) & $\sim 100--150$ (IV) \\
\hline cell width, $\mu \mathrm{m}$ & 48-65 (IV?) & $\sim 60-75^{\complement}$ (IV?) & nd & $81-113$ & nd & $\begin{array}{l}78.1-105.6 \\
\text { (OF) }\end{array}$ & 82-95 (IV?) & $\begin{array}{l}\sim 30--75^{b} \\
\text { (IV?) }\end{array}$ & $\begin{array}{l}\sim 30--75^{c} \\
\text { (IV?) }\end{array}$ & 50--75 (IV) \\
\hline $\begin{array}{l}\text { differentiation } \\
\text { of ventral } \\
\text { kinetom }\end{array}$ & - & $-\dagger$ & $+\dagger$ & nd & $-\dagger$ & + & $-\dagger$ & $+\dagger$ & $+\dagger$ & + \\
\hline $\begin{array}{l}\mathrm{n} \text { of ventro- } \\
\text { frontal kineties }\end{array}$ & nd & nd & nd & nd & nd & $\sim 30$ & nd & nd & nd & $12-18$ \\
\hline $\begin{array}{l}\mathrm{n} \text { of ventro- } \\
\text { lateral kineties }\end{array}$ & nd & nd & nd & nd & nd & $\sim 8 \dagger$ & nd & nd & nd & $8-13$ \\
\hline $\begin{array}{l}n \text { of ventral } \\
\text { kineties (total) }\end{array}$ & nd & $35-40$ & nd & nd & 24 & $\sim 38+$ & nd & nd & nd & $20-31$ \\
\hline $\begin{array}{l}\mathrm{n} \text { of dorsal } \\
\text { kineties }\end{array}$ & nd & $35-40$ & nd & nd & $20-30$ & 45 & nd & nd & nd & $25-31$ \\
\hline $\begin{array}{l}\text { composition } \\
\text { of somatic } \\
\text { kineties }\end{array}$ & nd & $\mathrm{dk}$ or $\mathrm{tk}$ & nd & nd & $d k$ & $\begin{array}{l}\text { mk; dk } \\
\text { within the } \\
\text { vestibular } \\
\text { cavity }\end{array}$ & nd & nd & nd & $\mathrm{mk}$ \\
\hline $\begin{array}{l}\mathrm{n} \text { and } \\
\text { composition } \\
\text { of oral kineties }\end{array}$ & nd & $\begin{array}{l}23+\text { prebuccal }+ \\
17+\text { postbuccal; nd }\end{array}$ & nd & nd & nd & $\begin{array}{l}30+ \\
\text { prebuccal + } \\
20 \dagger \\
\text { postbuccal; } \\
\text { dk }\end{array}$ & nd & nd & nd & $\begin{array}{l}25-30 \text { prebuccal + } 18-20 \\
\text { postbuccal; mk and dk }\end{array}$ \\
\hline $\begin{array}{l}\text { peristome size } \\
\text { : cell size ratio }\end{array}$ & $>1 / 2(\mathrm{IV})$ & $\sim 1 / 2 \dagger$ & $\sim 1 / 2$ & $\sim 1 / 2$ & $\sim 1 / 2$ & $\sim 1 / 2$ & $\sim 1 / 2$ & $\sim 1 / 2 \dagger$ & $<1 / 2 \dagger$ & $\sim 1 / 3$ \\
\hline $\begin{array}{l}\text { dsb size: cell } \\
\text { size ratio }\end{array}$ & nd & $\sim 1 / 2 \dagger$ & 1 & 1 & nd & 1 & nd & nd & nd & $+\sim 1$ \\
\hline $\begin{array}{l}\text { ma, length, } \\
\mu \mathrm{m}\end{array}$ & 15-20 (IV) & 35† (SI?) & nd & nd & $\sim 25+(\mathrm{PS})$ & $\begin{array}{l}20.9-33.0 \\
\text { (OF) }\end{array}$ & 25 & $\sim 20 \dagger$ & nd & 27 (average)(SI) \\
\hline ma, width, $\mu \mathrm{m}$ & 15-20 (IV) & 35† (SI?) & nd & nd & $\sim 25+(\mathrm{PS})$ & $\begin{array}{l}22.0-30.8 \\
\text { (OF) }\end{array}$ & 25 & $\sim 20 \dagger$ & nd & 32.5 (average) (SI) \\
\hline mi, number & 1 & nd & 1 & 1 & 1 & 1 & 1 & 1 & 1 & 1 \\
\hline $\begin{array}{l}\text { mi, diameter, } \\
\mu \mathrm{m}\end{array}$ & nd & nd & nd & nd & nd & nd & $4-7$ & nd & nd & 5.4 (average) \\
\hline exl, size, $\mu \mathrm{m}$ & 7-9 (IV) & 20 (SI??) & nd & nd & $22-26$ & nd & $6-10$ & nd & $\sim 20$ & 20 (IV) \\
\hline
\end{tabular}


Table 2 Comparison between the morphology and morphometry of Sonderia vorax and other similar-sized species of Sonderia according to selected literature data $^{\text {a }}$ (Continued)

\begin{tabular}{|c|c|c|c|c|c|c|c|c|c|c|}
\hline $\begin{array}{l}\text { exl, amount } \\
\text { and } \\
\text { distribution }\end{array}$ & $\begin{array}{l}\text { few; sparse and } \\
\text { unevenly distributed } \\
\text { throughout the cell }\end{array}$ & $\begin{array}{l}\text { many, inserted in } \\
\text { the cortex }\end{array}$ & nd & nd & nd & nd & $\begin{array}{l}\text { many, unevenly } \\
\text { distributed } \\
\text { throughout the } \\
\text { cellt }\end{array}$ & $\begin{array}{l}\text { many; } \\
\text { inserted } \\
\text { closely to } \\
\text { surface }+\end{array}$ & $\begin{array}{l}\text { many; } \\
\text { inserted } \\
\text { closely to } \\
\text { surface } †\end{array}$ & $\begin{array}{l}\text { many; inserted in the } \\
\text { cortex and sometimes } \\
\text { free in the cytoplasm }\end{array}$ \\
\hline $\begin{array}{l}\text { swimming } \\
\text { rotation }\end{array}$ & nd & nd & nd & nd & nd & nd & nd & nd & nd & anticlockwise \\
\hline $\begin{array}{l}\text { habitat } \\
\text { (salinity) }\end{array}$ & $\begin{array}{l}\text { hypersaline water } \\
(35-100 \% 0)\end{array}$ & $\begin{array}{l}\text { brackish water (1- } \\
6 \% 0)\end{array}$ & $\begin{array}{l}\text { brackish } \\
\text { water (3- } \\
20 \% \text { ) }\end{array}$ & seawater & brackish water & fresh water & $\begin{array}{l}\text { sea water ( } 35- \\
38 \% \text { ) }\end{array}$ & $\begin{array}{l}\text { brackish } \\
\text { water (5- } \\
20 \% \text { ) }\end{array}$ & $\begin{array}{l}\text { brackish } \\
\text { water (5- } \\
20 \% \text { ) }\end{array}$ & brackish water (4-8\%o) \\
\hline
\end{tabular}

${ }^{a}$, In Kahl [11] 7 species of Sonderia were included; in Carey [76] 8 Sonderia spp. were mentioned, but the majority of them were even more poorly described than those included in this table; ${ }^{b}$, original indication was "ratio lengh : width $2: 1^{\prime \prime} ;{ }^{c}$, original indication was "ratio lengh : width $21 / 2: 1$ "; + , character present; -, character absent; dsb, dorso-laterally striated band; exl, longer type extrusomes; IV, in vivo; ma, macronucleus; mk, monokinetids; mi, micronucleus; $\mathrm{n}$, number; nd, character not mentioned in the reference; + , character derived from pictures/drawings; OF, osmium tetroxide fixation; PS, protargol staining; $\mathrm{Sl}$, silver impregnation;

tk, trikinetids. 
Plagiopylida [23,30,31,46-52,54,55,66], we observed the absence of mitochondria and the presence of hydrogenosomes in S. vorax. Hydrogenosomes are descendents of mitochondria that anaerobically oxidize pyruvate to acetate and $\mathrm{CO}_{2}$, producing molecular hydrogen and ATP [67-70]; the organelles present in our species should reasonably cover the same functions.

In sulphide ciliates (among which there were two species of Sonderia) Fenchel et al. [46] described organelles called "microbodies", later identified as hydrogenosomes by Finlay \& Fenchel [30]. The similarity in the general aspect between the hydrogenosomes we found in our species and that of Sonderia spp. previously studied is restricted to electron density, double membrane bounding, irregular shape, granular matrix, and close contact with endoplasmic reticulum. The sizes, especially for the rod-shaped hydrogenosomes herein described, and the localization reported by Fenchel et al. [46] appear actually very different. Moreover, hydrogenosomes of different Sonderia spp. were not associated with endosymbiotic bacteria. This feature, not so far highlighted in Sonderia spp. [30,46], seems to be on the contrary widespread in Plagiopylida: besides our $S$. vorax, it was reported in Plagiopyla minuta and Lechriopyla mystax [47,48]; the latter species showed associations resembling those observed in P. frontata [51]. Furthermore, P. nasuta was recently restudied after successful cultivation [52], and was found to harbour two types of endosymbiotic bacteria: one of them, a methanogen, was almost always observed in very close association with hydrogenosomes. These "peculiar packets" appeared different to those observed in $P$. frontata; indeed, according to molecular analysis, they are different methanogens [19].

The endobacteria-hydrogenosomes associations we observed in our $S$. vorax resemble those described in $P$. minuta and L. mystax by Berger \& Lynn [48] and those reported in P. frontata by Finlay \& Fenchel [31] in their morphology and their frequent association with endoplasmic reticulum. Nevertheless, at variance with the bacteria described in the above mentioned papers and by Lynn [12] for the whole order Plagiopylida, the endobacteria we observed do not autofluoresce. Thus, they appear not to be methanogens. Although their identity cannot be directly established from our data, the negative results with the archeal probe in FISH experiments suggest that they probably belong to Eubacteria. This result is also in line with the observation of Fenchel \& Finlay [50] who already reported the presence in genus Sonderia of nonmethanogenic endosymbionts as notable exception among free-living ciliates bearing hydrogenosomes. Associations between hydrogenosomes and non-methanogenic bacteria in anaerobic ciliates were also reported by Finlay et al. [71] from a sulphide-rich solution lake in Spain, and by Clarke et al. [72] in the scuticociliate Cyclidium porcatum, which contains organized complexes of three different components: hydrogenosomes, methanogenic bacteria, and non-methanogenic bacteria.

To conclude this comparison of fine structure details within order Plagiopylida, in Trimyema spp. stable methanogenic endosymbiotic bacteria-hydrogenosomes associations were reported [23,55]. Finlay et al. [23] found that endosymbionts tend to change morphology aiming at maximizing the contact with hydrogenosomes. This feature was not observed in the non-methanogenic endosymbionts of our S. vorax, but several hydrogenosomes show irregular forms which tend to "embrace" endobacteria as to reach maximum contact with them.

Our TEM data are the first to reveal the presence in Sonderiidae of close associations between hydrogenosomes and endosymbiotic bacteria; thus, this feature can actually be considered typical of order Plagiopylida supporting Lynn [12]. Nevertheless, the endosymbionts involved in the arrangements are not methanogens. Of course it could be questionable whether our cells could have lost methanogenic endosymbiotic bacteria during their permanence in laboratory: for example, in Trimyema sp. rod-shaped methanogens were easily lost during monoclonal culturing, which lasted four years [55]. In spite of several attempts, we did not succeed to cultivate monoclonal strains of our species and we performed our experiments soon after collection of samples; this allows us to be pretty confident in our findings.

Finally, our species generally tends not to harbour endosymbiotic bacteria not associated with hydrogenosomes; this is again in contrast with the paper of Fenchel et al. [46], where "rod-shaped", "intracellular particles resembling bacteria" appeared mostly abundant directly beneath cell membranes of Sonderia spp. Nevertheless, looking at the pictures of those endosymbionts and considering only their general morphology (i.e. excluding size) they somehow resemble the bacteria we observed associated with hydrogenosomes in our species; this could mean that in the same species (or at least genus) the presence/absence of arrangements formed by hydrogenosomes and endosymbiotic bacteria is likely depending on ecological stimuli and/or constraints.

\section{Nuclei}

In stationary phase the macronuclear chromatin of S. vorax resembles that reported in some Heterotrichea (e.g. Chattonidium setense [29]; Peritromus kahli [37]). Concerning its fine structure, the micronucleus reminds of the compact type micronucleus described by Fokin [73].

\section{Phylogeny}

Our inference partially differs from that of $\mathrm{Xu}$ et al. [16] about the position of Parasonderia vestita. It was considered very closely related to Plagiopylidae in their article; in most of our trees it is instead more closely related to $S$. 
vorax and its associated environmental sequences. Both their result and ours are poorly supported, and we have demonstrated that the position of $P$. vestita can change according to how the character matrix is built. Thus, we prefer to leave the question of the Sonderiidae monophyly open, until more data will be obtained and a reliable topology could be inferred. The monophyly of genus Plagiopyla is not recovered, because the sequence of Lechriopyla mystax is nested inside those of the former genus. In none of the papers providing sequences of Plagiopylidae representatives a detailed morphological analysis of the studied organisms is supplied as well. Thus, the possibility that some of them were simply misidentified cannot be excluded. However, a more likely explanation is that the classical morphological characters employed to distinguish between these taxa are not good indicators of evolutionary relatedness, because either plesiomorphic or too vague. It is important to notice, however, that the morphologically similar Plagiopylidae and Sonderiidae do form a robust clade in molecular phylogeny: this clade is clearly separated from Trimyemidae, which members possess a distinctively different morphology.

There are many environmental sequences available in the databases that clearly cluster with characterized plagiopylean species. It is remarkable that all these sequences come from anoxic or suboxic, and often sulfidic, environments. S. vorax-like sequences were apparently obtained only from the Framvaren Fjord (North Sea, Norway) in two different studies [74,75]. Interestingly, the North Sea is also one of the places where Kahl originally collected ciliates of the genus Sonderia.

\section{Conclusions}

In the present paper we redescribed and neotypified the plagiopylid ciliate Sonderia vorax from a brackish water pond along the Italian coastlines. By means of the applied multidisciplinary analytical approach, more familiarity with the typical features of this poorly-known ciliate was gained. Moreover, in the light of the comparison between our findings and the scarce available literature on the order Plagiopylida, some previous systematics interpretations concerning this taxon were confirmed and some difficulties and ambiguities in the classification became as well evident. Our data significantly contribute to the general understanding of the overall diversity of the Plagiopylida. Nevertheless, it still remains a largely unexplored ciliate order: multidisciplinary analytical studies from a larger number of representatives are needed to clarify the phylogenetic relationships within this group.

\section{Diagnosis}

Sonderia vorax Kahl, 1928

1928 Sonderia vorax - Kahl, Archiv Hydrobiol 19:93-95, Figs 20a-c. [1]
1931 Sonderia vorax - Kahl, Tierwelt Dtl 21:269, Fig. 14. [11] 1934 Sonderia vorax - Kirby, Archiv Protistenknd 82:116. [7] 1969 Sonderia vorax - Fenchel, Ophelia 6:1-182. [6] 1972 Sonderia vorax - Borror, Acta Protozool 10:29-71. [2] 1992 Sonderia vorax - Carey, Marine Interstitial Ciliates 103-104, Fig. 359. [76]

\section{Diagnosis of neotype material}

Body dimensions in vivo: $~ 130 \times 69 \mu \mathrm{m}$ (on average). Outline body shape ovoid-ellipsoid with rounded ends, flattened up. On average 56 ciliary rows with ventral kinetom differentiated into two parts (ventral secant system): the ventro-frontal part ( $\sim 17$ rows on average) which breaks off posteriorly where it meets from the left the continuous ventro-lateral part $(\sim 11$ rows on average at the ventral surface left). Kineties composed of monokinetids placed at the top of cortical ridges. Depth of oral cavity never more than $1 / 3$ of body length. Oral ciliature arising in continuity with somatic ciliature; oral ciliature of the lower oral lip (18-20 postbuccal rows) consists of kineties perpendicularly inserted with respect to the upper oral lip kineties (25-30 prebuccal rows) and forms single ciliary membranelle-like rows. Dorso-laterally striated band arising near the right side of oral cavity and terminating near cell posterior end. A number of long needle-shaped extrusomes in body cortex visible under light microscope; a second smaller type visible only by TEM. A single contractile vacuole in the posterior part of the dorsal side of the cell. One quite large micronucleus of the "compact" type situated in the depression of the nearly spherical macronucleus. Different hydrogenosomes-endosymbiotic bacteria assemblages distributed throughout the cytoplasm, often in the neighbourhood of endoplasmic reticulum elements. Cell surface completely covered except for striated band by a layer of slightly curved, rod-shaped ectosymbiotic bacteria, arranged in parallel rows along interkinetal spaces. The ciliate rotates about main body axis always anticlockwise (left spiral swimming) and inhabits brackish water sites with oxygen deficiency (level 1-7\%).

\section{Neotypification and neotype material}

No useable type material (type or voucher slides) is available so far from any of Sonderia vorax populations $[15,17]$. The original description [1] is incomplete and apparently based on living observations only. Thus, it seems wise to define $S$. vorax by the designation of a neotype $[77,78]$. Validation of the neotype according to Article 75.3 of the ICZN [77] is justified by the following particulars: (i) the systematic status of $S$. vorax (it was considered as valid species after Kahl [1], but the description has never been improved according to a modern set of morphological methods); (ii) the differences between S. vorax and related taxa (see Discussion and Table 2); 
(iii) the neotype specimens (Figures 3A, 3B) representing neotype population from the Ligurian coastline pond (Pisa district, Tuscany, Italy) are described in details (see above); thus, recognition of the neotype designated is ensured; (iv) it is generally known that no type material is available from species described by Kahl; (v) there is strong evidence that the neotype is consistent with $S$. vorax as originally described by Kahl [1]; (vi) however, the neotype does not come from a site very near to the original type locality (Oldesloe salt marshes, Hamburg region, Germany). Neotype population of the ciliate was found in the middle part of Ligurian Sea (coastline pond nearby Serchio river mouth, Tuscany, Italy), roughly distance: $1000 \mathrm{~km}$; however, both sites are brackish water. Most ciliates, especially marine ones, are cosmopolitans [79], hence this point should not be over-interpreted. A detailed description of the new type locality, that is the sample site of the neotype population, is given in Material and Methods; (vii). One neotype slide of silver nitrateimpregnated specimens (slide № S-11), collected from the pond in Ligurian coastline, Pisa district, Tuscany, Italy, (sampling date 05 October 2005; collector S. I. Fokin), one permanent Feulgen staining preparation (slide № S-17), and Epon-embedded material for TEM investigation have been deposited in the collection of the Museo di Storia Naturale e del Territorio dell'Università di Pisa, Calci (PI), Italy. Two further neotype slides of silver nitrateimpregnated specimens (slides № S-12 and S-14) have been deposited in the slide collection of the Laboratory of Invertebrate Zoology, Biological Research Institute, St. Petersburg State University, St. Petersburg, Russia.

\section{Neotype locality}

Owing to the neotypification, the sampling site of the neotype population is the new (valid) type locality of Sonderia vorax: brackish water pond along the coastline of Ligurian Sea close to Serchio River mouth (Pisa district, Tuscany, Italy; $\left.43^{\circ} 47^{\prime} 16^{\prime \prime} \mathrm{N}, 10^{\circ} 16^{\prime} 02^{\prime \prime} \mathrm{E}\right)$.

\section{Etymology}

The derivation of the species-group name is in the original description by Kahl [1].

\section{Gene sequence}

The $18 \mathrm{~S}$ rRNA gene sequence of $S$. vorax is available under the accession number [EMBL: HF547270].

\section{Abbreviations}

SEM: Scanning electron microscope/Microscopy; TEM: Transmission electron microscope/Microscopy; FISH: Fluorescence in situ hybridization; PCR: Polymerase chain reaction.

\section{Authors' contribution}

LM and GR performed SEM and TEM analyses and the comparative research on the related literature; SIF performed in vivo, silver-staining and FISH analyses, and reviewed the species identification problem; IA and FF obtained the 185 rRNA gene sequence; VB performed the phylogenetic analyses; FV and GP supervised the work and provided advices on the draft. All authors read and approved the final manuscript.

\section{Acknowledgments}

This research was partly supported by a grant from the Italian Ministry of University and Research - MIUR (Ministero Italiano dell'Università e della Ricerca) to S. I. Fokin

The authors wish to thank S. Gabrielli for technical assistance with photographic work.

\section{Author details}

${ }^{1}$ Unit of Protistology-Zoology, Department of Biology, University of Pisa, via A. Volta 4/6, Pisa 56126, Italy. ${ }^{2}$ Department of Invertebrate Zoology, St. Petersburg State University, Universitetskaya emb. 7/9, St. Petersburg 199034, Russia.

Received: 28 November 2012 Accepted: 8 February 2013

Published: 18 February 2013

\section{References}

1. Kahl A: Die Infusorien (Ciliata) der Oldesloer Salzwasserstellen. Arch Hydrobiol 1928, 19:50-123.

2. Borror AC: Tidal marsh ciliates (Protozoa: morphology, ecology and systematics). Acta Protozool 1972, 10:29-71.

3. Czapik A, Jordan A: Les ciliés psammophiles de la mer Baltique aux environs de Gdánsk. Partie I. Acta Protozool 1976, 15:423-446.

4. Dragesco J, Dragesco-Kernéis A: Cilies libres de l'Afrique intertropicale. Faune Tropicale 1986, 26:1-559.

5. Fauré-Fremiet E, Tuffrau M: Sonderia labiata, n. sp., cilié trichostome psammobie. Hydrobiologia 1955, 7:210-218.

6. Fenchel T: The ecology of marine microbenthos. IV. Structure and function of the benthic ecosystem, its chemical and physical factors and the microfauna communities with special reference to the ciliated protozoa. Ophelia 1969, 6:1-182.

7. Kirby H: Some ciliates from salt marshes in California. Arch Protistenkd 1934, 82:114-133.

8. Modeo L, Fokin SI, Ferrantini F, Rosati G, Verni F: Morphological and ultrastructural study on the plagiopylid ciliate Sonderia sp. Kahl, 1928. J Eukaryot Microbiol 2007, 54:76a.

9. Sola A, Guinea A, Longás JF, Fernández-Galiano D: Quelques observations sur le cilie Sonderia sinuata Kahl, 1931 (Ciliophora, Trichostomatida). Arch Protistenkd 1989, 137:1-8.

10. Corliss JO: The ciliated protozoa. Characterization, classification, and quide to the literature. 2nd edition. Oxford, New York, Toronto, Sydney, Paris, Frankfurt: Pergamon Press; 1979.

11. Kahl A: Urtiere oder Protozoa. 1: Wimpertiere oder Ciliata (Infusoria). 2. Holotricha außer den im 1. Teil behandeiten Prostomata. Tierwelt Dtl 1931, 21:181-398

12. Lynn DH: The ciliated protozoa. Characterization, classification, and guide to the literature. 3rd edition. Germany: Springer; 2008.

13. Lynn DH, Small EB: Phylum Ciliophora. In An illustrated guide to the Protozoa. 2nd edition. Edited by Lee JJ, Hutner SH, Bovee EC. Lawrence (KS), USA: Allen Press; 2000:371-655.

14. Fauré-Fremiet E: Le genre Parasonderia n. g. C R Acad Sci 1973, 276:2011-2014.

15. Jankowski AW: Phylum Ciliophora Doflein, 1901. In Handbook on Zoology, Part 2. Protista. Edited by Alimov AF. St. Petersburg: Zoological Institute Press, Russian Academy of Sciences; 2007:415-993. In Russian with English summary.

16. Xu Y, Shao C, Miao M, Song W: Redescription of Parasonderia vestita (Kahl, 1928) comb. nov. (Ciliophora, Plagiopylida), with notes on its phylogeny based on SSU rRNA gene. Eur J Protistol. doi:10.1016/j.ejop.2012.03.001. in press.

17. Aescht E: Catalogue of the generic names of ciliates (Protozoa, Ciliophora). Denisia 2001, 1:1-350.

18. Foissner W, Wenzel F: Life and legacy of an outstanding ciliate taxonomist, Alfred Kahl (1877-1946), including a facsimile of his forgotten monograph from 1943. Acta Protozool 2004, 43(Suppl):3-69.

19. Embley TM, Finlay BJ, Dyal PL, Hirt RP, Wilkinson M, Williams AG: Multiple origins of anaerobic ciliates with hydrogenosomes within the radiation of aerobic ciliates. Proc R Soc Lond B Biol Sci 1995, 262:87-93. 
20. Zhang $\mathrm{Q}$, Simpson A, Song W: Insights into the phylogeny of the systematically controversial haptorian ciliates (Ciliophora, Litostomatea) based on multigene analyses. Proc R Soc Lond B Biol Sci 2012, 279:2625-2635.

21. Lynn DH, Strüder-Kypke M: Phylogenetic position of Licnophora, Lechriopyla, and Schizocaryum, three unusual ciliates (Phylum Ciliophora) endosymbiotic in echinoderms (Phylum Echinodermata). J Eukaryot Microbiol 2002, 49:460-468

22. Baumgartner M, Stetter KO, Foissner W: Morphological, small subunit rRNA, and physiological characterization of Trimyema minutum Kahl, 1931, an anaerobic ciliate from submarine hydrothermal vents growing from $28^{\circ} \mathrm{C}$ to $52^{\circ} \mathrm{C}$. J Eukaryot Microbiol 2002, 49:227-238.

23. Shinzato N, Watanabe I, Meng XY, Sekiguchi Y, Tamaki H, Matsui T, Kamagata $Y$ : Phylogenetic analysis and fluorescence in situ hybridization detection of archaeal and bacterial endosymbionts in the anaerobic ciliate Trimyema compressum. Microb Ecol 2007, 54:627-636.

24. Cho BC, Park JS, Xu K, Choi JK: Morphology and molecular phylogeny of Trimyema koreanum n. sp., a ciliate from the hypersaline water of a solar saltern. J Eukaryot Microbiol 2008, 55:417-426

25. Stoeck T, Foissner W, Lynn DH: Small-subunit rRNA phylogenies suggest that Epalxella antiquorum (Penard, 1922) Corliss, 1960 (Ciliophora, Odontostomatida) is a member of the Plagiopylea. J Eukaryot Microbiol 2007, 54:436-442.

26. Skovorodkin IN: A device for immobilization of small biological objects during light microscopical observation. Tsitologiia 1990, 32:87-91. In Russian with English summary.

27. Foissner W: Colpodea (Ciliophora). Stuttgart, Jena, New York: Gustav Fisher Verlag; 1993

28. Corliss JO: Silver impregnation of ciliated protozoa by the Chatton-Lwoff technique. Stain Technol 1953, 28:97-100.

29. Modeo L, Rosati G, Andreoli I, Gabrielli G, Verni F, Petroni G: Molecular systematics and ultrastructural characterization of a forgotten species: Chattonidium setense (Ciliophora, Heterotrichea). Proc Jpn Acad B Phys 2006, 82:359-374.

30. Finlay BJ, Fenchel T: Hydrogenosomes in some anaerobic protozoa resemble mitochondria. FEMS Microbiol Lett 1989, 65:311-314.

31. Finlay BJ, Fenchel T: An aerobic protozoon, with symbiotic methanogens, living in municipal landfill material. FEMS Microbiol Ecol 1991, 85:169-180.

32. Ferrantini F, Fokin SI, Modeo L, Andreoli I, Dini F, Görtz H-D, Verni F, Petroni G: "Candidatus Cryptoprodotis polytropus", a novel Rickettsia-like organism in the ciliated protist Pseudomicrothorax dubius (Ciliophora, Nassophorea). J Eukaryot Microbiol 2009, 56:119-129.

33. Amann Rl, Krumholz I, Stahl DA: Fluorescent oligonucleotide probing of whole cells for determinative, phylogenetic, and environmental studies in microbiology. J Bacteriol 1990, 172:716-770.

34. Stahl DA, Amann R: Development and application of nucleic acid probes In Nucleic acid techniques in bacterial systematics. Edited by Stackebrandt E, Goodfellow M. Chichester, United Kingdom: John Wiley \& Sons Ltd; 1991:205-248.

35. Medlin L, Elwood HJ, Stickel S, Sogin ML: The characterization of enzymatically amplified 16S-like rRNA-coding regions. Gene 1988, 71:491-499.

36. Petroni G, Dini F, Verni F, Rosati G: A molecular approach to the tangled intrageneric relationships underlying phylogeny in Euplotes (Ciliophora, Spirotrichea). Mol Phylogenet Evol 2002, 22:118-130.

37. Rosati G, Modeo L, Melai M, Petroni G, Verni F: A multidisciplinary approach to describe protists: a morphological, ultrastructural, and molecular study on Peritromus kahli Villeneuve-Brachon, 1940 (Ciliophora, Heterotrichea). J Eukaryot Microbiol 2004, 51:49-59.

38. Pruesse E, Quast C, Knittel K, Fuchs B, Ludwig W, Peplies J, Glöckner FO: SILVA: a comprehensive online resource for quality checked and aligned ribosomal RNA sequence data compatible with ARB. Nucleic Acids Res 2007, 35:7188-7196.

39. Ludwig W, Strunk O, Westram R, Richter L, Meier H, Yadhukumar, Buchner A, Lai T, Steppi S, Jobb G, Förster W, Brettske I, Gerber S, Ginhart AW, Gross O, Grumann S, Hermann S, Jost R, König A, Liss T, Grumann S, Hermann S, Jost R, König A, Liss T, Lüßmann R, May M, Nonhoff B, Reichel B, Strehlow R, Stamatakis A, Stuckmann N, Vilbig A, Lenke M, Ludwig T, Bode A, Schleifer $\mathrm{KH}$ : ARB: a software environment for sequence data. Nucleic Acids Res 2004, 32:1363-1371.

40. Guindon S, Gascuel O: A simple, fast, and accurate algorithm to estimate large phylogenies by maximum likelihood. Syst Biol 2003, 52:696-704.
41. Posada D: jModelTest: phylogenetic model averaging. Mol Biol Evol 2008, 25:1253-1256

42. Schmidt HA, Strimmer $K$, Vingron M, von Haeseler A: TREE-PUZZLE: Maximum likelihood phylogenetic analysis using quartets and parallel computing. Bioinformatics 2002, 18:502-504

43. Huelsenbeck JP, Ronquist F: MRBAYES: Bayesian inference of phylogenetic trees. Bioinformatics 2001, 17:754-755.

44. Small EB, Lynn DH: In An illustrated guide to the Protozoa. Edited by Lee JJ, Hutner SH, Bovee EC. Kansas, USA: Society of Protozoologists, Lawrence; 1985:393-575

45. Al-Rasheid KAS: New records of interstitial ciliates (Protozoa, Ciliophora) from the Saudi coasts of the Red Sea. Trop Zool 2001, 14:133-156.

46. Fenchel $T$, Perry $T$, Thane A: Anaerobiosis and symbiosis with bacteria in free-living ciliates. J Protozoo/ 1977, 24:154-163.

47. Berger J, Lynn DH: Somatic and oral cortical ultrastructure of the plagiopylid ciliates Lechriopyla mystax Lynch, 1930 and Plagiopyla minuta Powers, 1933. J Protozool 1984, 31:433-443.

48. Berger J, Lynn DH: Hydrogenosomes-methanogen assemblages in the echinoid endocommensal plagiopylid ciliates, Lechriopyla mystax Lynch, 1930 and Plagiopyla minuta Powers, 1933. J Protozool 1992, 39:4-8.

49. Embley TM, Finlay BJ: The use of small subunit rRNA sequences to unravel the relationships between anaerobic ciliates and their methanogen endosymbionts. Microbiology 1994, 140:225-235.

50. Fenchel T, Finlay BJ: The biology of free-living anaerobic ciliates. Eur J Protistol 1991, 26:201-215.

51. Fenchel T, Finlay BJ: Synchronous division of an endosymbiotic methanogenic bacterium in the anaerobic ciliate Plagiopyla frontata Kahl. J Protozool 1991, 38:22-28.

52. Goosen NK, Horemans AMC, Hillebrand SJW, Stumm CK, Vogels GD: Cultivation of the sapropelic ciliate Plagiopyla nasuta Stein and isolation of the endosymbiont Methanobacterium formicicum. Arch Microbiol 1988, 150:165-170.

53. de Puytorac P, Groliére JC, Detcheva R, Grain J: Observations sur I'ultrastructure du cilié Vestibulifera, Plagiopyla nasuta Stein, 1860. Ann Sci Nat Zool 1985, 7:189-198. in French with English summary.

54. Detcheva R, de Puytorac P, Grolière CA: Some ultrastructural characteristics of the polysaprobic ciliate Trimyema compressum. Trans Am Microsc Soc 1981, 100:65-73.

55. Finlay BJ, Embley TM, Fenchel T: A new polymorphic methanogen, closely related to Methanocorpusculum parvum, living in stable symbiosis within the anaerobic ciliate Trimyema sp. J Gen Microbio/ 1993, 139:371-378.

56. Rinke C, Schmitz-Esser S, Stoecker K, Nussbaumer AD, Molnár DA, Vanura K, Wagner M, Horn M, Ott JA, Bright M: "Candidatus Thiobios zoothamnicoli", an ectosymbiotic bacterium covering the giant marine ciliate Zoothamnium niveum. Appl Environ Microbiol 2006, 72:2014-2021.

57. Rosati G: Epixenosomes: symbionts of the hypotrich ciliate Euplotidium itoi. Symbiosis 1999, 26:1-23.

58. Modeo L, Petroni G, Lobban CS, Verni F, Vannini C: Morphological, ultrastructural, and molecular characterization of Euplotidium rosati n. sp. (Ciliophora, Euplotida) from Guam. J Eukaryot Microbiol 2013, 60:25-36.

59. Breglia SA, Yubuki N, Hoppenrath M, Leander BS: Ultrastructure and molecular phylogenetic position of a novel euglenozoan with extrusive epysimbiotic bacteria: Bihospites bacati n. gen. et sp. (Symbiontida). BMC Microbiol 2010, 10:145. doi:10.1186/1471-2180-10-145.

60. Yubuki N, Edgcomb VP, Bernhard JM, Leander BS: Ultrastructure and molecular phylogeny of Calkinsia aureus: cellular identity of a novel clade of deep-sea euglenozoans with epibiotic bacteria. BMC Microbiol 2009, 9:16. doi:10.1186/1471-2180-9-16.

61. Simpson AGB, van Den Hoff J, Bernard C, Burton HR, Patterson DJ: The ultrastructure and systematic position of the euglenozoon Postgaardi mariagerensis, Fenchel et al. Arch Protistenkd 1996, 147:213-225.

62. Fokin SI: Frequency and biodiversity of symbionts in representatives of the main classes of Ciliophora. Eur J Protistol 2012, 48:138-148.

63. Fokin SI, Modeo L, Andreoli I, Ferrantini F, Verni F, Petroni G: Rare ciliate species (Ciliophora, Protista) revealed from brackish water habitats with oxygen deficiency. Paris, Book of Abstracts: International Congress of Zoology; 2008:31.

64. Hausmann K: Extrusive organelles in Protists. Int Rev Cytol 1978, 52:197-276

65. Rosati G, Modeo L: Extrusomes in ciliates: diversification, distribution, and phylogenetic implications. J Eukaryot Microbiol 2003, 50:383-402. 
66. Broers CAM, Stumm CK, Vogels GD: Axenic cultivation of the anaerobic free-living ciliate Trimyema compressum. J Protozool 1991, 38:507-511.

67. Benchimol M: Hydrogenosomes under microscopy. Tissue Cell 2009, 41:151-168.

68. Embley TM, Martin W: Eukaryotic evolution, changes and challenges. Nature 2006, 30:623-630

69. Müller M: The hydrogenosomes. J Gen Microbiol 1993, 139:2235-2241.

70. Van der Giezen M: Hydrogenosomes and mitosomes: conservation and evolutions of functions. J Eukaryot Microbiol 2009, 56:221-231.

71. Finlay BJ, Clarke KJ, Vicente E, Miracle MR: Anaerobic ciliates from a sulphide-rich solution lake in Spain. Eur J Protistol 1991, 27:148-159.

72. Clarke KJ, Finlay BJ, Esteban G, Guhl BE, Embley TM: Cyclidium porcatum n. sp.: a free-living anaerobic scuticociliate containing a stable complex of hydrogenosomes, eubacteria and archeobacteria. Eur J Protistol 1993, 29:262-270.

73. Fokin SI: Morphological diversity of the micronuclei in Paramecium. Arch Protistenkd 1997, 148:376-387.

74. Behnke A, Barger KJ, Bunge J, Stoeck T: Spatio-temporal variations in protistan communities along an $\mathrm{O}_{2} / \mathrm{H}_{2} \mathrm{~S}$ gradient in the anoxic Framvaren Fjord (Norway). FEMS Microbiol Ecol 2010, 72:89-102.

75. Behnke A, Bunge J, Barger K, Breiner HW, Alla V, Stoeck T: Microeukaryote community patterns along an $\mathrm{O}_{2} / \mathrm{H}_{2} \mathrm{~S}$ gradient in a supersulfidic anoxic fjord (Framvaren, Norway). Appl Environ Microbiol 2006, 72:3626-3636

76. Carey PG: Marine interstitial ciliates. An illustrated key. London, New York: Chapman \& Hall; 1992.

77. International Commission on Zoological Nomenclature (ICZN): International Code of Zoological Nomenclature. London: International Trust For Zoological Numenclature; 1999.

78. Foissner W: Neotypification of protists, especially ciliates (Protozoa, Ciliophora). Bull Zool Nom 2002, 59:165-169.

79. Finlay BJ, Corliss JO, Esteban GF, Fenchel T: Biodiversity at the microbial level: the number of free-living ciliates in the biosphere. Q Rev Biol 1996, 71:221-237.

do: 10.1186/1471-2180-13-40

Cite this article as: Modeo et al:: Morphology, ultrastructure, and molecular phylogeny of the ciliate Sonderia vorax with insights into the systematics of order Plagiopylida. BMC Microbiology 2013 13:40

\section{Submit your next manuscript to BioMed Central and take full advantage of:}

- Convenient online submission

- Thorough peer review

- No space constraints or color figure charges

- Immediate publication on acceptance

- Inclusion in PubMed, CAS, Scopus and Google Scholar

- Research which is freely available for redistribution 